\title{
Neuroplastin expression is essential for hearing and hair cell PMCA expression
}

\author{
Xiao Lin ${ }^{1,2} \cdot$ Michael G. K. Brunk ${ }^{3}(-) \cdot$ Pingan Yuanxiang $^{4}\left(\mathbb{0} \cdot\right.$ Andrew W. Curran $^{5}$ (D) Enqi Zhang $^{6} \cdot$ Franziska Stöber $^{5}$.

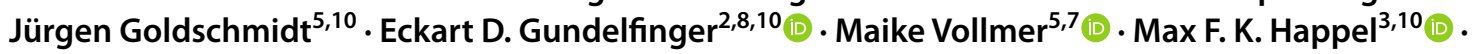 \\ Rodrigo Herrera-Molina ${ }^{2,9,10} \cdot$ Dirk Montag $^{1}$ (1)
}

Received: 28 May 2020 / Accepted: 27 March 2021 / Published online: 12 April 2021

(c) The Author(s) 2021

\begin{abstract}
Hearing deficits impact on the communication with the external world and severely compromise perception of the surrounding. Deafness can be caused by particular mutations in the neuroplastin ( Nptn) gene, which encodes a transmembrane recognition molecule of the immunoglobulin (Ig) superfamily and plasma membrane Calcium ATPase (PMCA) accessory subunit. This study investigates whether the complete absence of neuroplastin or the loss of neuroplastin in the adult after normal development lead to hearing impairment in mice analyzed by behavioral, electrophysiological, and in vivo imaging measurements. Auditory brainstem recordings from adult neuroplastin-deficient mice $\left(\mathrm{Nptn}^{-/-}\right)$show that these mice are deaf. With age, hair cells and spiral ganglion cells degenerate in $\mathrm{Nptn}^{-/-}$mice. Adult $\mathrm{Nptn}^{-/-}$mice fail to behaviorally respond to white noise and show reduced baseline blood flow in the auditory cortex (AC) as revealed by single-photon emission computed tomography (SPECT). In adult $\mathrm{Nptn}^{-/-}$mice, tone-evoked cortical activity was not detectable within the primary auditory field (A1) of the AC, although we observed nonpersistent tone-like evoked activities in electrophysiological recordings of some young $\mathrm{Nptn}^{-/-}$mice. Conditional ablation of neuroplastin in $\mathrm{Nptn}{ }^{\text {lox/loxEmxlCre }}$ mice reveals that behavioral responses to simple tones or white noise do not require neuroplastin expression by central glutamatergic neurons. Loss of neuroplastin from hair cells in adult $N p t n^{\Delta l o x / l o x P r C r e E R T}$ mice after normal development is correlated with increased hearing thresholds and only high prepulse intensities result in effective prepulse inhibition (PPI) of the startle response. Furthermore, we show that neuroplastin is required for the expression of PMCA 2 in outer hair cells. This suggests that altered $\mathrm{Ca}^{2+}$ homeostasis underlies the observed hearing impairments and leads to hair cell degeneration. Our results underline the importance of neuroplastin for the development and the maintenance of the auditory system.
\end{abstract}

Keywords Neuroplastin $\cdot$ Deafness $\cdot$ Hearing $\cdot$ Auditory cortex $\cdot$ Cochlea $\cdot$ Hair cells $\cdot$ Plasma membrane Calcium ATPase $\cdot$ PMCA

Dirk Montag

montag@lin-magdeburg.de

1 Neurogenetics Laboratory, Leibniz Institute for Neurobiology, Brenneckestr. 6, 39118 Magdeburg, Germany

2 Department Neurochemistry and Molecular Biology, Leibniz Institute for Neurobiology, Brenneckestr. 6, 39118 Magdeburg, Germany

3 Department System Physiology and Learning, AG CortXplorer, Leibniz Institute for Neurobiology, Brenneckestr. 6, 39118 Magdeburg, Germany

4 Research Group Neuroplasticity, Leibniz Institute for Neurobiology, Brenneckestr. 6, 39118 Magdeburg, Germany

5 Department System Physiology and Learning, Leibniz Institute for Neurobiology, Brenneckestr. 6, 39118 Magdeburg, Germany
6 Institute of Medical Psychology, Otto-Von-Guericke University Magdeburg, University Hospital, Leipziger Str. 44, 39120 Magdeburg, Germany

7 Department of Otolaryngology-Head and Neck Surgery, Otto-Von-Guericke University Magdeburg, University Hospital, Leipziger Str. 44, 39120 Magdeburg, Germany

8 Medical Faculty, Molecular Neuroscience, Otto-Von-Guericke University Magdeburg, University Hospital, Leipziger Str. 44, 39120 Magdeburg, Germany

9 Centro Integrativo de Biología Y Química Aplicada, Universidad Bernardo O’Higgins, 8307993 Santiago, Chile

10 Center for Behavioral Brain Sciences (CBBS), 39106 Magdeburg, Germany 


\section{Introduction}

Hearing impairments compromise perception of the surrounding and alter communication with the external world. The recent finding that particular mutations in the neuroplastin gene (Nptn) can lead to deafness (Carrott et al. 2016; Zeng et al. 2016) attracted interest in the functions of neuroplastin in the hearing system.

Neuroplastin is a phylogenetically conserved type I glycoprotein belonging to the immunoglobulin superfamily (Langnaese et al. 1997; for review, see Beesley et al. $2014 a$, b). Polymorphisms in the regulatory region of the human NPTN gene correlate with cortical thickness and intellectual abilities in adolescents (Desrivières et al. 2014) and were detected in individuals suffering from schizophrenia (Saito et al. 2007). Recently, the NPTN gene has been associated with heart rate (Choy et al. 2018) and lung cancer (Sumardika et al. 2019). Expression of the $65 \mathrm{kD}$ neuroplastin (Np65) isoform derived by alternative splicing from the Nptn gene is restricted to brain neurons, whereas the $55 \mathrm{kD}$ isoform (Np55) is present in most cell types but not e.g. in glia (Langnaese et al. 1997). Neuroplastin has been shown to interact as a ligand with the fibroblast growth factor (FGF) receptor (Owczarek et al. 2010), gamma-aminobutyric acid type A (GABAA) receptors (Sarto-Jackson et al. 2012), S100A8/A9, basigin (Sakaguchi et al. 2016; Sumardika et al. 2019), mesencephalic astrocyte-derived neurotrophic factor (MANF) (Yagi et al. 2020), tumor necrosis factor receptor-associated factor 6 (TRAF6) (Vemula et al. 2020), and with itself undergoing homophilic binding (Langnaese et al. 1997; Owczarek et al. 2010). Furthermore, plasma membrane trafficking of monocarboxylic acid transporter 2 (MCT-2, SLC16A7) and $\mathrm{XK}$-related protein $8(\mathrm{Xkr} 8)$ may require neuroplastin as chaperone (Wilson et al. 2013; Suzuki et al. 2016).

Recently, it was shown that the expression of plasma membrane $\mathrm{Ca}^{2+}$ ATPases (PMCAs) critically depends on neuroplastin (Bhattacharya et al. 2017; Herrera-Molina et al. 2017) and that neuroplastin engages in tight contact forming functional complexes with PMCAs (HerreraMolina et al. 2017; Korthals et al. 2017; Schmidt et al. 2017; Gong et al. 2018). In the absence of neuroplastin, PMCA levels are reduced resulting in elevated intracellular $\mathrm{Ca}^{2+}$ levels and prolonged decay time to reach resting $\mathrm{Ca}^{2+}$ levels after stimulation (Herrera-Molina et al. 2017; Korthals et al. 2017; Schmidt et al. 2017).

The functions of neuroplastin were also addressed by investigation of targeted mouse mutants with specific loss of only the Np65 isoform (Amuti et al. 2016; Li et al. 2019), complete loss of neuroplastin (Nptn ${ }^{\text {tm1.2Mtg }}$, Bhattacharya et al. 2017), conditional loss in glutamatergic neurons (Nptn ${ }^{\text {lox/loxEmxlCre }}$, Herrera-Molina et al. 2017), or inducible conditional neuron-specific mutants (Nptnlox/loxPr-CreERT, Bhattacharya et al. 2017). These studies proved that neuroplastin is important for multiple pathways and functions. Loss of neuroplastin affects cellular functions as $\mathrm{Ca}^{2+}$ homeostasis, long-term potentiation, synapse formation, and more (Bhattacharya et al. 2017; Korthals et al. 2017) resulting ultimately in pronounced deficits including male infertility, depression-like behavior, and learning and memory deficits in Nptn mutants (Bhattacharya et al. 2017). Np65 appears to serve particular functions related to cognitive functions and the synaptic balance (Amuti et al. 2016; Li et al. 2019). Strikingly, induced loss of neuroplastin from neurons in adult mice induces retrograde amnesia specifically of associative memories (Bhattacharya et al. 2017).

Recently, the neuroplastin gene was identified as a deafness gene (Carrott et al. 2016). The mutants audio- 1 (I122N), pitch (C315S), and Y219X, generated by $N$-ethyl$N$-nitrosaurea (ENU) mutagenesis, and two insertional EUCOMM mutants (insertional mutant Nptn intron 3 and $\mathrm{Nptn}^{\text {tmlb(EUCOMM }) \mathrm{Hmgu}}$ with deletion of Ig3 and transmembrane encoding Nptn exons 5 and 6) are associated with progressive hearing impairment or deafness (Zeng et al. 2016; Carrott et al. 2016). The common feature of these ENU-generated and EUCOMM mutants is the possibility of expression of truncated and/or instable or altered neuroplastin proteins possibly leading to gain of function and/ or negative effects rather than loss of neuroplastin function. Indeed, the extracellular part of neuroplastin or peptides thereof can mimic several functions of neuroplastin (Smalla et al. 2000; Empson et al. 2006; Owczarek et al. 2010, 2011; Herrera-Molina et al. 2014). Furthermore, Zeng et al. (2016) propose the requirement of $\mathrm{Np55}$ expression by outer hair cells needed for cochlear amplification, whereas Carrott et al. (2016) propose Np65 driven synaptogenesis by inner hair cells as necessary for hearing. In addition, these studies disagree on the localization of neuroplastin and the expression of its isoforms in the cochlea.

In this study, we investigate with targeted mutants that cannot express altered or truncated neuroplastin isoforms whether the complete absence of neuroplastin or its loss in adulthood result in deafness and interfere with the central auditory perception and processing. Here, we analyze hearing properties in mice completely lacking neuroplastin, or with conditional loss of neuroplastin in glutamatergic neurons, or with induced neuroplastin loss in adult neurons after normal development. Furthermore, we show that PMCA2 expression in cochlear hair cells depends on neuroplastin, suggesting aberrant $\mathrm{Ca}^{2+}$ extrusion in hair cells as the causal mechanism underlying hearing impairments in neuroplastin mutants. Our results show that neuroplastin is required not only during the development of the hearing system but also for the maintenance of hearing capabilities in the adult. 


\section{Materials and methods}

\section{Animals}

Neuroplastin-deficient mice $\mathrm{Nptn}^{-1-}\left(\mathrm{Nptn}^{\mathrm{tm} 1.2 \mathrm{Mtg}}\right)$ and floxed $N p t n^{l o x / l o x}$ mice with neuron-specific inducible PrCreERT (Nptn ${ }^{\text {lox/loxPrCreERT }}$ ) or with conditional loss in glutamatergic neurons (Nptn $\left.{ }^{\text {lox/loxEmxlCre }}\right)$ were described (Bhattacharya et al. 2017; Herrera-Molina et al. 2017). A schematic illustration of the mutated neuroplastin alleles and Cre-mediated recombination for these mouse mutants is provided in Suppl. Fig S1A. PrCreERT was activated by daily i.p. injection of $200 \mu \mathrm{l}$ tamoxifen $10 \mathrm{mg} / \mathrm{ml}$ in medical oil for 10 days. All experiments were conducted with adult ( $>3$ months of age) mice, except when stated otherwise. Mice were kept with a 12-h light/dark cycle and food and water ad libitum. All procedures were in accordance with institutional, state, and government regulations and approved by an ethics committee.

\section{Behavioral tests}

Sex- and age-matched littermate $\mathrm{Nptn}^{+/+}$mice served as controls for $\mathrm{Nptn}^{-/-}$mice, and $\mathrm{Nptn}{ }^{l o x / l o x}$ mice as controls for $\mathrm{Nptn}^{\Delta l o x / l o x P r C r e E R T}$ and Nptn ${ }^{\text {lox/loxEmxlCre }}$ mice. The experimenter was not aware of the genotype.

Associative learning was assessed by two-way active avoidance in a two-chambered shuttle-box (TSE Systems $\mathrm{GmbH}$ ) with $10 \mathrm{~s}$ of white noise $6 \mathrm{kHz}$ as conditioning (CS) and electrical foot shock as unconditioned stimulus $(5 \mathrm{~s}, 0.3 \mathrm{~mA}$ pulsed) delivered after the CS (80 trials/day, $5-15 \mathrm{~s}$ of stochastically varied intertrial intervals for 5 consecutive days). Compartment changes during CS were counted as conditioned avoidance reactions. The acoustic startle response to a stimulus $(50 \mathrm{~ms}, 120 \mathrm{~dB})$ and its inhibition by prepulses (PPI) $(30 \mathrm{~ms} ; 100 \mathrm{~ms}$ before startle stimulus with eight different intensities, 73-94 dB, 3-dB increments, $70 \mathrm{~dB}$ white noise background) was analyzed in a startle-box system (TSE Systems GmbH). Habituation ( $3 \mathrm{~min}$ ) was followed by two startle trials and in pseudorandom order by 10 startle trials and five trials at each prepulse intensity with stochastically varied intertrial intervals $(5-30 \mathrm{~s})$. The maximal startle amplitude was measured by a sensor platform. Fear conditioning was conducted as described (Schilling et al. 2008). Mice were conditioned in an operant chamber (San Diego Instruments) by exploration ( $2 \mathrm{~min}$ ) and auditory cue presentation $(15 \mathrm{~s})$, followed by a foot shock $(2 \mathrm{~s}, 1.5 \mathrm{~mA}$ unpulsed) with one repetition. Twenty-four hours later, mice were placed in the training chamber (context, 5 min) and then returned to their home cage. One hour later, mice were placed in a novel environment $(3 \mathrm{~min})$ and then the auditory cue (CS) was presented ( $3 \mathrm{~min}$ ). Freezing behavior (immobility) was recorded during all sessions.

\section{Thalamocortical brain slice recording}

The horizontal thalamocortical brain slices (Cruikshank et al. 2002) were prepared from 4-5-month-old animals $\left(\mathrm{Nptn}^{+/+}\right.$and $\left.\mathrm{Nptn}^{-/-}\right)$, and then pre-incubated for $1 \mathrm{~h}$ in carbogenated $\left(95 \% \mathrm{O}_{2}-5 \% \mathrm{CO}_{2}\right)$ artificial cerebrospinal fluid (ACSF, containing in mM: $110 \mathrm{NaCl}, 2.5 \mathrm{KCl}, 2.5$ $\mathrm{CaCl}_{2} \cdot 2 \mathrm{H}_{2} \mathrm{O}, 1.5 \mathrm{MgSO}_{4} \cdot 7 \mathrm{H}_{2} \mathrm{O}, 1.24 \mathrm{KH}_{2} \mathrm{PO}_{4}, 10$ glucose, $27.4 \mathrm{NaHCO}_{3}, \mathrm{pH}$ 7.3) at room temperature. One slice at a time was transferred into a slice recording chamber (Scientific Systems Inc.) and allowed to recover for at least $30 \mathrm{~min}$. The local complex field potentials were obtained from layer 2/3 pyramidal neurons in primary auditory cortex (A1). This intra-cortical pathway was activated with $0.9 \% \mathrm{NaCl}$ filled glass capillary microelectrodes $(3-5 \mathrm{M} \Omega$ ). The local complex field potentials were recorded and amplified by an extracellular amplifier (EXT-02B, npi, Germany) and digitized at a sample frequency of $20 \mathrm{kHz}$ by AD/DA converter (POWER 1401mkII, CED, UK). The stimulation strength was adjusted to $30-40 \%$ of the maximum field potential values.

\section{In vivo electrophysiology}

\section{Surgical procedure and recording}

Surgery and preparation of mice for the acute experiment (2-month-old $\mathrm{Nptn}^{-/-}, n=6 ; 5$-month-old $\mathrm{Nptn}^{-/-}, n=3$; 2-month-old $\mathrm{Nptn}^{+/+}, n=6 ; 5$-month-old $\mathrm{Nptn}^{+/+}, n=7$ ) were conducted as described in detail previously (Happel et al. 2010; Deliano et al. 2018; Brunk et al. 2019). Briefly, animals were anesthetized by intraperitoneal injection $(0.007 \mathrm{ml} / \mathrm{g})$ of $20 \%$ Ketavet $(100 \mathrm{mg} / \mathrm{ml}$, Zoetis), $5 \%$ xylazine (2\% Rompun, BayerVital), and $75 \%$ isotonic sodium chloride solution ( $0.9 \mathrm{~g} / \mathrm{l}$, Berlin Chemie).

Based on the vascularization pattern and confirmed by tonotopic mapping, we identified the $\mathrm{AC}$ region and implanted a 32-channel single-shank recording electrode (Neuronexus A1x32-50-413; channel impedances between 500 and $800 \mathrm{k} \Omega$ ) perpendicular to the AC surface.

Local field potentials (LFPs) were recorded in response to pure tones $(100 \mathrm{~ms}$, inter-stimulus interval $800 \mathrm{~ms}$, 50 repetitions per tone, $1-32 \mathrm{kHz}$ ) at $75 \mathrm{~dB}$ SPL. We further presented a pause condition (no sound presentation) and a condensed click condition (Saldeitis et al. 2014) at $75 \mathrm{~dB}$ SPL. All stimuli were generated via Matlab (2007), converted into an analog signal by a data acquisition card (NI PCIBNC2110, National Instruments, Germany), rooted through a controllable attenuator (gPAH, Guger, Technologies, 
Austria), and amplified by an audio amplifier (Thomas Tech Amp75). Sounds were presented in an acoustic far field environment of $1 \mathrm{~m}$ distance between speaker (Tannoy arena KI-8710-32) and the animal.

After implantation, LFPs were recorded for up to $2 \mathrm{~h}$ to allow cortical activity to stabilize (Deane et al. 2020). For final data analysis, we chose sets of stimulus repetitions with stabilized responses. Experiments were conducted in an acoustically and electrically shielded recording chamber. Recorded signals were pre-amplified (500X) and bandpass filtered between 3 and $170 \mathrm{~Hz}$ by a PBX2 preamplifier, and then digitized at $1 \mathrm{kHz}$ with a multichannel-recording system (Multichannel Acquisition Processor, Plexon Inc.).

\section{Current source density (CSD) analysis}

Based on the tone- and click-evoked local field potentials (LFPs), a one-dimensional current-source density (CSD) profile was derived from the second spatial derivative of the laminar LFP (Mitzdorf 1985):

$-\mathrm{CSD} \approx \frac{\delta^{2} \varnothing(z)}{\delta z^{2}}=\frac{\varnothing(z+n \Delta z)-2 \varnothing(z)+\varnothing(z-n \Delta z)}{(n \Delta z)^{2}}$.

The formula reflects the relation of the field potential $(\varnothing)$, the spatial coordinate of the cortical laminae $(z)$, the interchannel distance $(\Delta z, 50 \mu \mathrm{m})$ and the differentiation grid (n). Prior to CSD calculation, LFPs were smoothed using a weighted average of 7 channels (Hamming window, spatial filter kernel size of $300 \mu \mathrm{m}$ ). We extrapolated the edge channels from the recorded LFPs to retain the channels' information within the corresponding CSDs (Happel et al. 2010).

Based on click-evoked CSD profiles, cortical layers (I/ II, III/IV and V/VI) could be identified based on the early granular sink components, that have been shown to reflect direct thalamocortical input into cortical layers III-IV. Cortical layers I/II, and V/VI were assigned accordingly (Happel et al. 2010; Deliano et al. 2018).

By rectifying and averaging the waveforms of the CSDs for each channel $(n)$, we can describe the overall evoked cortical activity along the recording electrode without the cancellation effects of sink and source activities. This average rectified CSD (AVREC) provides a temporal waveform of the overall local columnar transmembrane current flow (Givre et al. 1994; Schroeder et al. 1998).

$\operatorname{AVREC}=\frac{\sum_{i=1}^{n}\left|\mathrm{CSD}_{i}\right|(t)}{n}$.

Within the resulting AVREC traces, the highest evoked peak amplitude within the first $50 \mathrm{~ms}$ after click presentation was determined and compared with the corresponding time window of the pause condition for all animals.

\section{Single photon emission computed tomography (SPECT)-imaging}

Small animal SPECT-imaging of cerebral blood flow (CBF) was performed in vivo for mapping spatial patterns of neuronal activity as published previously (Bhattacharya et al. 2017; Kolodziej et al. 2014). In short, $\mathrm{Nptn}^{-/-}$mice $(n=7)$ and control $\mathrm{Nptn}^{+/+}$mice $(n=10)$ were injected via catheters in the right external jugular vein with $54.47 \pm 8.83 \mathrm{MBq}$ of ${ }^{99 \mathrm{~m}} \mathrm{Tc}$ hexamethylpropyleneamine oxime $\left({ }^{99 \mathrm{~m}} \mathrm{Tc}-\mathrm{HMPAO}\right)$ with a flow rate of $50 \mu \mathrm{l} / \mathrm{min}$. After ${ }^{99 \mathrm{~m}} \mathrm{Tc}-\mathrm{HMPAO}$-injection animals were anesthetized and scanned using a four head NanoSPECT/CT scanner (Mediso, Hungary). CT and SPECT images were co-registered. CT scans were made at $45 \mathrm{kVp}, 177 \mu \mathrm{A}$, with 180 projections, $500 \mathrm{~ms}$ per projection, and reconstructed with the manufacturer's software (InVivoScope 1.43) at isotropic voxel-sizes of $100 \mu \mathrm{m}$. For SPECT-imaging, 24 projections were acquired during a total scan time of $2 \mathrm{~h}$. Axial field of view (FOV) was $20.9 \mathrm{~mm}$. Energy windows were set to the default values of the NanoSPECT/CT $(140 \mathrm{keV} \pm 5 \%)$. SPECT images were reconstructed using the iterative algorithm of the manufacturer's software (HiSPECT, SCIVIS, Goettingen, Germany) at isotropic voxel output sizes of $167 \mu \mathrm{m}$. SPECT/CT images were manually aligned to a high-resolution MR mouse brain data set (Ma et al. 2005, 2008) based on skull-landmarks of the CTs with the MPI-Tool software (version 6.36, Advanced Tomo Vision, Kerpen, Germany). SPECT brain data were cut out of the SPECT data in Osirix (64-bit, version 5.7.1; Pixmeo, SARL, Bernex, Switzerland) using a whole-brain volume-of-interest (VOI) (Ma et al. 2005, 2008). Brain SPECT data were global mean normalized using the MPITool software. For data analysis, brain ${ }^{99 \mathrm{~m}} \mathrm{Tc}$-distributions in $\mathrm{Nptn}^{-/-}$mice vs. controls were compared with data sets from a previous study (Herrera-Molina et al. 2017) where

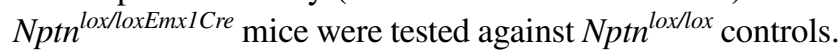

\section{Auditory brainstem responses (ABR)}

Animals were anesthetized by intraperitoneal injection $(0.007 \mathrm{ml} / \mathrm{g})$ of $20 \%$ Ketavet $(100 \mathrm{mg} / \mathrm{ml}$, Zoetis), $5 \%$ xylazine (2\% Rompun, BayerVital), and $75 \%$ isotonic sodium chloride solution ( $0.9 \mathrm{~g} / \mathrm{l}$, Berlin Chemie) before auditory testings were performed in a single-walled, sound-attenuated, and electrically shielded chamber (Industrial Acoustics, Germany). Stimulus generation and ABR recordings were performed using Tucker-Davis-Technologies (TDT, USA) System 3 hardware. To assess neural sensitivity to acoustic stimulation of the cochleae, ABRs were measured to low rate $(21 \mathrm{~Hz})$ acoustic click stimuli $(50 \mu \mathrm{s})$. Acoustic stimuli were digitally generated by a real-time processor (RX8, $100 \mathrm{k}$ samples/s; Vollmer 2018; Wiegner et al. 2016) and passed through a programmable attenuator (PA5). 
Stimuli were amplified (AMP84; Thomas Wulf Elektronik) and delivered by a free-field speaker (MF1) located in front of the animal's head. Prior to recordings, stimulus levels were calibrated to $\mathrm{dB}$ pSPL (Burkard 2006) using a probe microphone (46 BE 1/4"; G.R.A.S.) and conditioning amplifier (Nexus 2690, B\&K). The distance between speaker and microphone was $4 \mathrm{~cm}$, corresponding to the distance between the speaker and the animal's ear canals. For recordings, subcutaneous electrodes were placed in the posterior midline of the neck (active), the snout (reference), and the back (ground) of the animal. ABRs were recorded using TDT System 3 software (BioSigRP: $21 \mathrm{~Hz}, 500-1500$ repetitions). Recordings were amplified (RA4LI), digitized (RA4PA; $25 \mathrm{k}$ samples/s), and filtered (RX5: 300-3000 Hz, $50 \mathrm{~Hz}$ notch filter). The ABR threshold was defined as the lowest stimulation level that evoked a reproducible response according to visual criteria. Thresholds were tested up to a maximum stimulus level of $90 \mathrm{~dB}$.

\section{Immunofluorescent staining}

For immunohistochemistry, at least three animals for each genotype were analyzed. Adult mice were anesthetized with isoflurane and transcardially perfused with PBS followed by $4 \%$ PFA. Cochleae were dissected and post-fixed in 4\% PFA overnight. After fixation, PFA was removed and replaced with $0.1 \mathrm{M}$ EDTA for decalcification. Then, the organ of Corti was isolated and processed for immunofluorescence. Cochlear whole mounts were blocked (20\% horse serum and $1 \%$ Triton X-100 in DPBS, $1 \mathrm{~h}$, room temperature) and incubated with primary antibodies in the same blocking buffer (overnight, $4{ }^{\circ} \mathrm{C}$ ). Primary antibodies were sheep polyclonal neuroplastin detecting Np65 and Np55 (pan-Np55/65) and goat polyclonal Np65 isoform-specific (1:500, R\&D systems), mouse monoclonal pan-PMCA clone 5F10 (1:1000, Abcam), rabbit anti-PMCA1 and rabbit anti-PMCA2 (1:500, Thermo Scientific), rabbit anti- $\beta$-III Tubulin (TUJ) (1:1000, Synaptic Systems), rabbit anti-Myosin7a (1:1000, BD Bioscience), mouse anti-Parvalbumin (1:500, Swant). Secondary antibodies were $\mathrm{Cy} 3$-conjugated anti-sheep, Cy5-conjugated anti-rabbit or -goat, Alexa Fluor 488 anti-mouse or rabbit (1:1000, Jackson Immunoresearch), phalloidin-iFluor 488 green (1:1000, Abcam), and Sox-2 (E-4) Alexa Fluor 647 (1:300, Santa Cruz). After washing with PBS and briefly with water, the sections were mounted on glass slides with fluoromount $\mathrm{g}$ DAPI (Southern Biotech) and were visualized using a Leica SP5 confocal microscope.

\section{Quantification of cochlear cells}

The quantification of cells was performed as described (Perny et al. 2016). Briefly, for the hair cell analysis, whole mount preparations of cochlea were labeled with antibodies identifying hair cells (Myosin 7a). Only the co-labeled Myosin7a and DAPI-positive hair cells were counted in the preparations. 300-400 HCs were analyzed for each cochlea area (apical, middle, and basal turns). The total number of hair cells was normalized to the length of the basilar membrane and the cell number per $100 \mu \mathrm{m}$ was calculated. For spiral ganglion neuron (SGN) counting, the density of SGNs was analyzed by counting both TUJ- and DAPI-positive cells in the midmodilar plane (apical, middle, and basal turns). Three nonconsecutive sections were selected from a total of 20 sections for analysis. The number of SGNs from each region was divided by the area of corresponding Rosenthal's canal.

\section{Western blot of brain and cochlear proteins}

Whole brain and cochleae were dissected from adult mice and homogenized in $50 \mathrm{mM}$ Tris- $\mathrm{HCl}$ buffer ( $\mathrm{pH}$ 8.1) with protease inhibitor cocktail (Roche). The crude membranes were extracted by adding lysis buffer $(50 \mathrm{mM}$ Tris- $\mathrm{HCl}, 1 \%$ Triton X-100 and protease inhibitor cocktail, pH 8.1). Following incubation for $1 \mathrm{~h}$ on ice, the supernatant was collected centrifugation at $12,000 \mathrm{~g}$ for $20 \mathrm{~min}$. Samples were denatured with $2 \times$ SDS loading buffer for $5 \mathrm{~min}$ at $95^{\circ} \mathrm{C}$, analyzed by western blot and probed overnight with anti-Np65 and -Np55 (pan-Np55/65; 1:5000) or goat polyclonal isoform-specific anti-Np65 (1:5000) antibodies (R\&D systems). After incubation for $1 \mathrm{~h}$ with anti-sheep or -goat IgG secondary antibody (1:8000, Jackson ImmunoResearch) and washing with TBS containing $0.5 \%$ Tween 20 , the membrane was developed with ECL solution (Intas Chemocan ECL Imaging).

\section{Statistical analysis}

For behavioral experiments and ABR, Statview (SAS Institute, Inc., Cary, NC) was used for analysis of variance, post hoc analysis (Scheffé or Fisher's protected least significant difference), repeated-measures analysis of variance, and $t$ tests. $p<0.05$ was considered significant. For quantification of cells, analysis of variance with Dunnett's multiple comparisons test was performed using Prism (version 9, GraphPad Software) In the voxelwise analysis, unpaired $t$ tests were calculated to compare brain ${ }^{99 \mathrm{~m}} \mathrm{Tc}$ distributions using the MagnAn-software (version 2.4, BioCom, Germany) and uncorrected $p$ values as usual in small-animal radionuclide imaging studies (Endepols et al. 2010; Thanos et al. 2013; Wyckhuys et al. 2010). For CSD analysis, a two-sample $t$ test between Pause and Click conditions was performed within each group. For local complex field potential analysis, the Mann-Whitney $U$ test was used for group comparisons. 
A

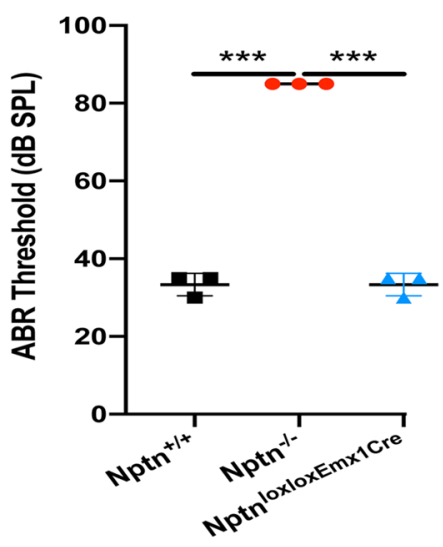

C

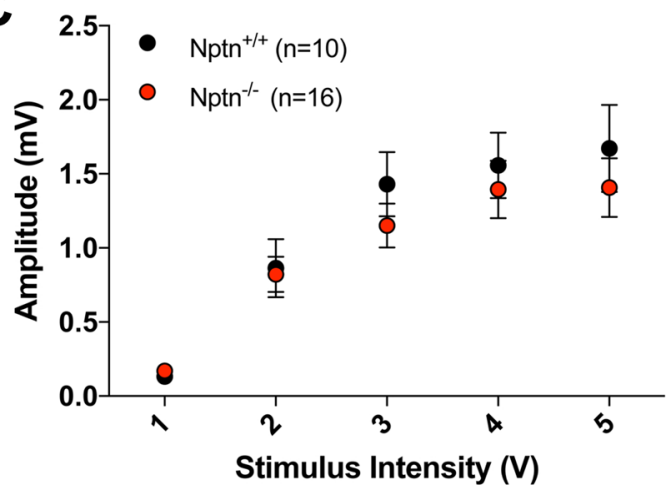

$\mathbf{E}$

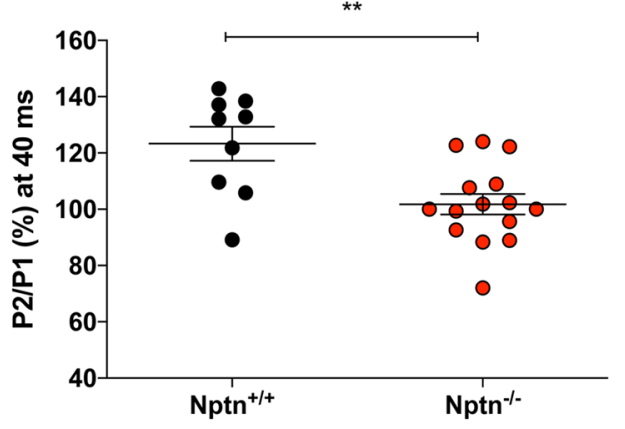

\section{Results}

\section{Hearing deficits and acoustic brainstem responses (ABR) of adult Nptn ${ }^{-/-}$mice}

Previously, we observed that adult neuroplastin-deficient mice $\left(\mathrm{Nptn}^{-/-}\right.$, Suppl. Fig. S1A) hardly reacted with a startle response to a $120 \mathrm{~dB}$ stimulus and accordingly did not show PPI of the startle response (Bhattacharya et al. 2017).
B

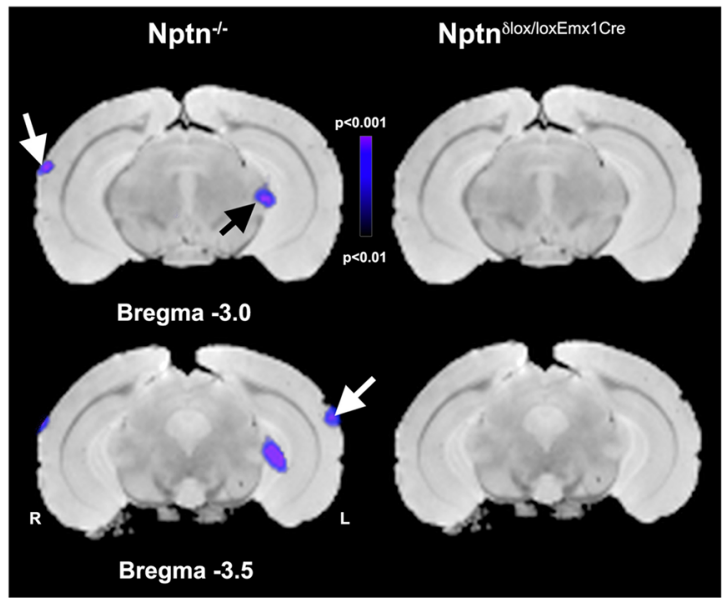

D

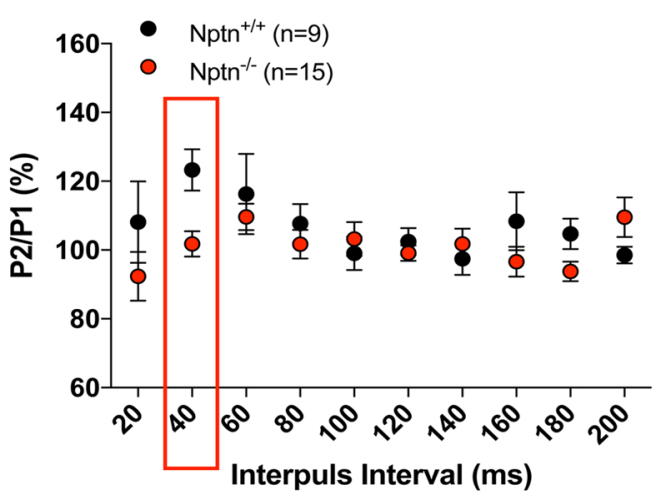

Interpuls Interval (ms)

Here, we confirmed the inability of adult $\mathrm{Nptn}^{-/-}$mice to process auditory information using a sound associated twoway active avoidance task with white noise as the auditory conditioning stimulus (Suppl. Fig. S1B-D). To further evaluate the possibility of processing deficits in the auditory periphery, we evaluated acoustic brainstem responses (ABR) to transient click stimuli. The hearing threshold of 4-month-old adult $\mathrm{Nptn}^{-/-}$mice $(n=3,90 \mathrm{~dB})$ was significantly higher than in wild-type littermate controls $(n=3$, 
४Fig. 1 Auditory brainstem responses (ABR) and baseline activity in the auditory cortex of $\mathrm{Nptn}^{-/-}$and $\mathrm{Nptn}^{\text {loxloxEmxlCre mice and basal }}$ synaptic transmission in $\mathrm{Nptn}^{-/-}$mice. A Comparison of auditory brainstem responses (ABR) to clicks between 4-month-old adult $\mathrm{Nptn}^{+/+}, \mathrm{Nptn}^{-/-}$, and 3-month-old Nptn lox/loxEmxICre mice. ABR thresholds in $\mathrm{Nptn}^{-/-}(n=3$, red circles) were significantly higher in comparison to $\mathrm{Nptn}^{+/+}(n=3$, black squares) and Nptn lox/loxEmxICre $\left(n=3\right.$, blue triangles) mice (one-way ANOVA $F_{(2,6)}=480.5$; $* * * p \leq 0.0001)$. Thresholds in $\mathrm{Nptn}^{-/-}$mice reached our criterion for deafness $(>85 \mathrm{~dB})$. B Significant changes in cerebral blood flow as determined by SPECT in $\mathrm{Nptn}^{-/-}(n=7)$ and Nptn ${ }^{\text {loxloxEmxlCre }}$ mice $(n=9)$ as compared to controls $(n=10)$. Shown are maps of $p$ values in the range of $p<0.01$ to $p<0.001$ overlaid on reference MRIs at two different distances from Bregma. In $\mathrm{Nptn}^{-/-}$but not in Nptnlox/loxEmxlCre mice, blood flow decreases significantly in the auditory system (white arrows point to the AC, black arrow to the medial geniculate body). C In brain slices of the AC, input/output (I/O) curves of local complex field potential amplitude revealed no differences in basal synaptic transmission between wild-type $\mathrm{Nptn}^{+/+}$mice (black, $n=10$ slices) and $\mathrm{Nptn}^{-/-}$mice (red, $n=16$ slices). The data are presented as means \pm SEM. D Short-term plasticity as evaluated by paired-pulse facilitation was significantly decreased at the $40 \mathrm{~ms}$ interval in the AC of $\mathrm{Nptn}^{-/-}$mice (red, $n=15$ slices) compared to wild-type $\mathrm{Nptn}^{+/+}$(black, $n=9$ slices). The data are presented as means \pm SEM. $\mathbf{E}$ Individual paired-pulse facilitation measurements at the $40 \mathrm{~ms}$ interval indicating reduced synaptic release probability characteristics (effect of genotype: Mann-Whitney $U$ test: ${ }^{* *} p<0.01$ )

30-40 dB; $p<0.0001$ ) (Fig. 1A) and revealed deafness in $\mathrm{Nptn}^{-/-}$mice similar as reported for the previously characterized neuroplastin mutants (Carrott et al. 2016; Zeng et al. 2016). In contrast, the ABR in 3-month-old mutants with conditional loss of neuroplastin only in glutamatergic neurons (Nptn ${ }^{\text {lox/loxEmxlCre }}$ mice, $n=3$ ) was similar to control mice (Fig. 1A).

\section{Auditory cortex activities in $\mathrm{Nptn}^{-/-}$mice}

The functional behavioral failure to respond to the startle sound and to the white noise-conditioning stimulus and the hearing impairment identified by ABR may also be reflected in $\mathrm{AC}$ activities. Therefore, we imaged baseline brain activities by single-photon emission computed tomography (SPECT) of cerebral blood flow. In the resting state with background noise, adult $\mathrm{Nptn}^{-/-}$mice display substantially and significantly reduced baseline blood flow in the auditory system compared to wild-type littermates. In the AC and in the medial geniculate body, tracer content was more than $15 \%$ higher in controls than in $\mathrm{Nptn}^{-/-}$mice and peak significance values were lower than $p<0.01$ (Fig. 1B). Significance levels peaked in the upper layers of $\mathrm{AC}$, but blood flow decreased over all layers. Interestingly, $\mathrm{Nptn}^{\text {lox/loxEmxlCre }}$ mice with normal ABR display unchanged resting state activities in the AC (Fig. 1B) and normal startle responses and prepulse inhibition (Suppl. Fig. S1E), indicating that neuroplastin expressed by glutamatergic neurons is neither required for perception nor processing of auditory information.
To investigate whether neuroplastin is involved in signal processing in the auditory cortex, we analyzed synaptic transmission in the primary auditory cortex (A1) by field recording (Fig. 1C) in brain slices from adult mice. The input/output (I/O) curves of local complex field potential amplitude did not differ between wild-type and $\mathrm{Nptn}^{-/-}$mice indicating monosynaptic transmission. However, with short interpulse intervals of $40 \mathrm{~ms}$, the release probability was significantly $(p=0.0087)$ reduced in $\mathrm{Nptn}^{-/-}$compared to wildtype mice (Fig. 1D, E), indicating slightly altered release properties. A similar effect was also observed for Schaffer collaterals in the hippocampus of $\mathrm{Nptn}^{-/-}$mice (Bhattacharya et al. 2017).

To further test the responsiveness of the $\mathrm{AC}$ in $\mathrm{Nptn}^{-/-}$mice to auditory stimuli in vivo, we used multichannel electrophysiological recordings in response to pure tone and click stimulation (75 dB SPL) in anaesthetized animals (Suppl. Fig. S2). Auditory evoked CSD analysis provides a sensitive measure of postsynaptic current flow of synaptic populations and identification of cortical layers (Happel et al. 2010). In young (2-month-old) and adult (5-month-old) $\mathrm{Nptn}^{+/+}$animals, we found a typical canonical CSD pattern of sensory evoked processing with early synaptic inputs resembling thalamocortical input of layers III/IV and subsequent sink activity across supragranular layers I/ II and infragranular V/VI layers (Suppl. Fig. S2A, B). Click evoked AVREC responses were significantly higher than cortical activity during the pause condition in both 2- and 5-month-old mice (Suppl. Fig. S2C, left; two-sample Student's $t$-test; 2-month-old $\mathrm{Nptn}^{+/+}, p=0.0075$; 5-month-old $\mathrm{Nptn}^{+/+}, \mathrm{p}=0.0323$ ). In comparison, $\mathrm{Nptn}^{-/-}$mice showed substantially altered cortical response patterns. At the age of 2 months, two of six $\mathrm{Nptn}^{-/-}$mice demonstrated residual cortical responses to a salient pure tone stimulus (Suppl. Fig. S2A, right). However, both 2- and 5-month-old $\mathrm{Nptn}^{-/-}$mice showed only weak CSD responses to transient clicks (Suppl. Fig. S2B). Accordingly, the averaged rectified CSD during a $100 \mathrm{~ms}$ time window after the click presentation was not significantly different from a pause condition without acoustic stimulation (2-month-old $\mathrm{Nptn}^{-/-}, p=0.6714$; 5-monthold $\mathrm{Nptn}^{-/-}, p=0.6768$; Suppl. Fig. S2C). These findings revealed that $\mathrm{Nptn}^{-/-}$mice show severely suppressed auditory responses in $\mathrm{AC}$ in young animals already at the level of thalamocortical synaptic input. Although this indicates malfunctional auditory processing already at subcortical stages, the effects might still be related to central gain processing deficits (Deane et al. 2020).

\section{Expression of neuroplastin in the cochlea}

Previous work provided limited and conflicting information on the expression of neuroplastin in the cochlea. Carrot et al. (2016) detected Np65 located at the cuticular plate of IHC 
and $\mathrm{OHC}$ and the basolateral region of IHC and could not detect Np55, whereas Zeng et al. (2016) found expression of Np55/65 by spiral ganglia, stereocilia of outer and vestibular hair cells, and the basolateral membrane but were unable to analyze Np65. Therefore, we analyzed expression of neuroplastin in the cochlea of adult wild-type mice in comparison to $\mathrm{Nptn}^{-/-}$and Nptn ${ }^{\text {lox/loxEmxICre }}$ mice (Fig. 2). In wild-type mice, we detected neuroplastin expression by inner and outer hair cells using antibodies against all $\mathrm{Np}$ isoforms (Figs. 2A, B, 3A). In contrast, we could not detect any labeling of inner or outer hair cells using antibodies specific for Np65 (Fig. 3A, B), whereas expression of Np65
Fig. 2 Expression of neuroplastin in inner and outer hair cells of the cochlea. A, B Cochlear whole mounts of $\mathrm{Nptn}^{+/+}$, $\mathrm{Nptn}^{-/-}$, and $\mathrm{Nptn}{ }^{\text {lox/loxEmxlCre }}$ mice were labeled with phalloidin-iFluor 488 green (Phal), DAPI, and antibodies against neuroplastin 55 and 65 (Nptns) and PMCA1 (A) or PMCA2 (B). Neuroplastin was detected in inner and outer hair cells $\left(b, b^{\prime}, j, j^{\prime}\right)$ and colocalized with PMCA1 (c, g, k) in inner $(\mathrm{d}, \mathrm{l})$ or with PMCA2 $\left(\mathrm{c}^{\prime}, \mathrm{g}^{\prime}, \mathrm{k}^{\prime}\right)$ in outer hair cells $\left(\mathrm{d}^{\prime}, \mathrm{l}^{\prime}\right)$. Scale bar $=15 \mu \mathrm{m}$ in $\mathrm{i}$ and $\mathrm{i}^{\prime}$
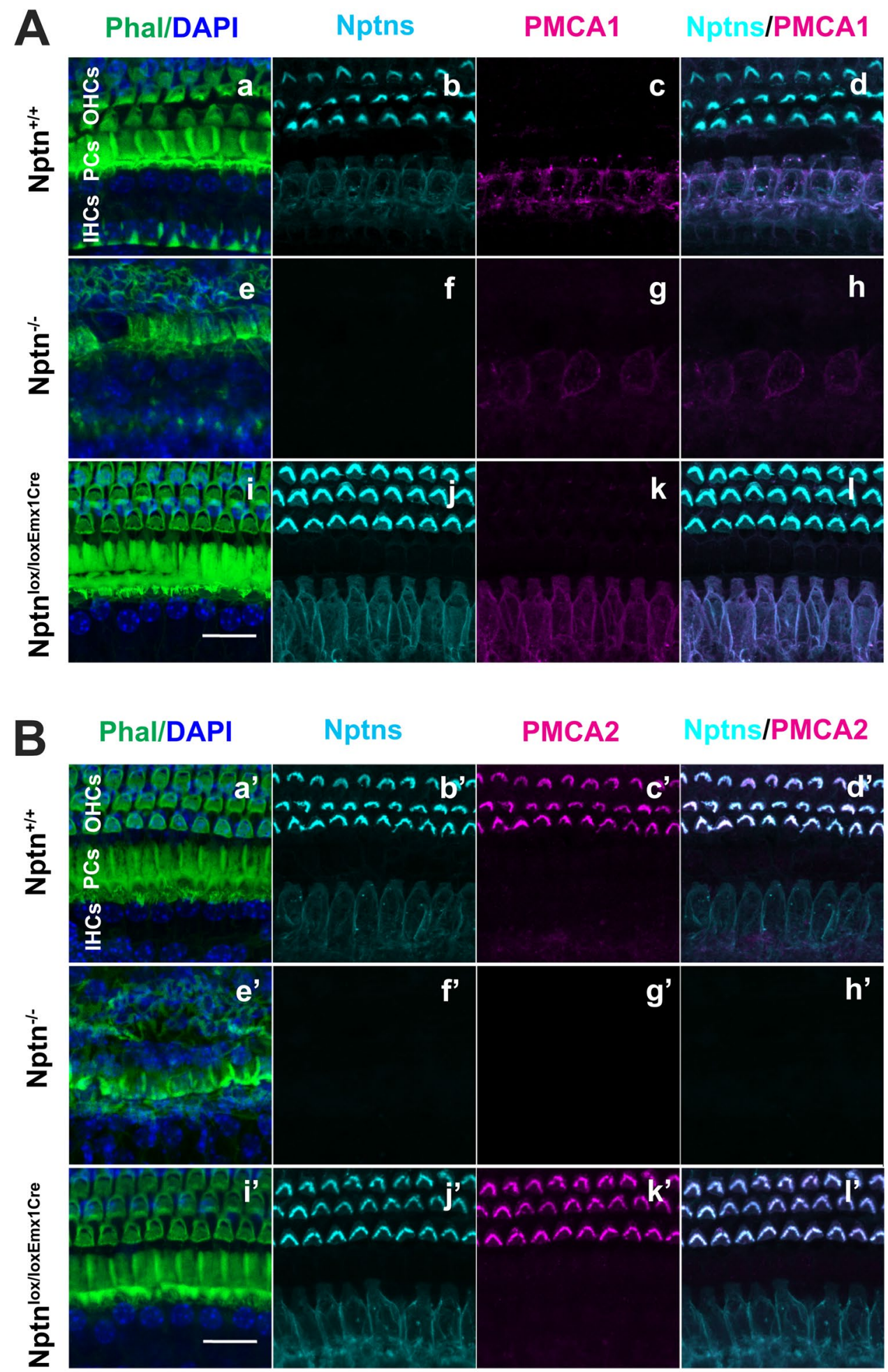


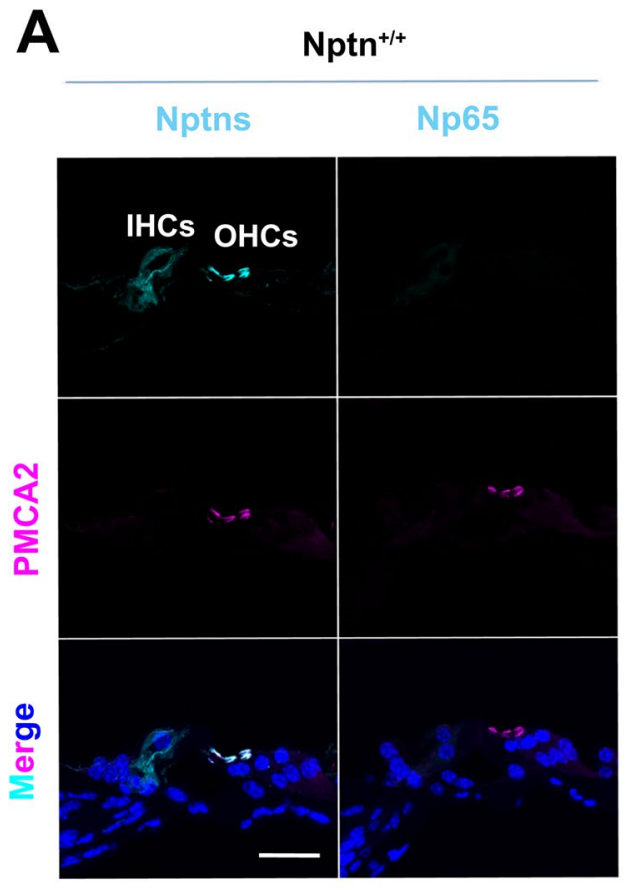

B
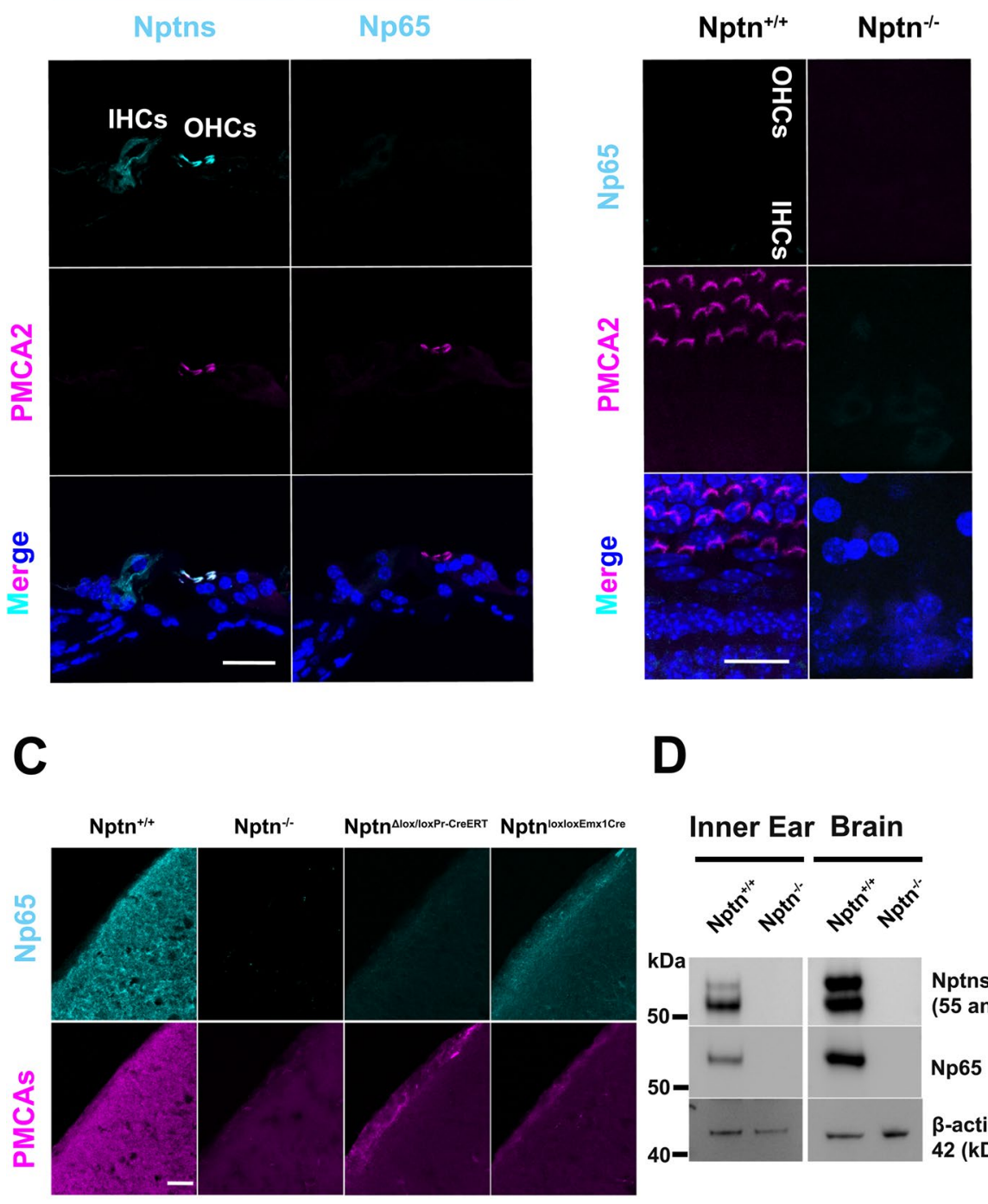

D

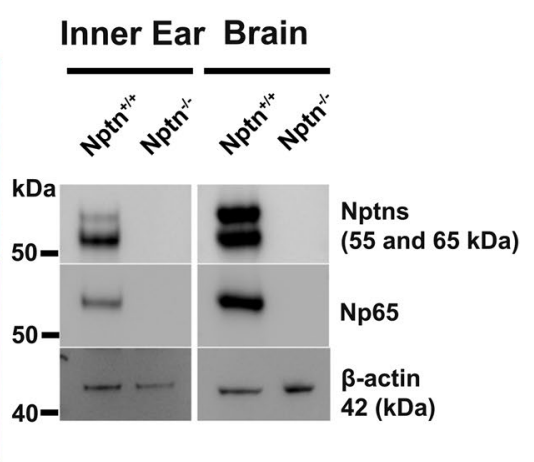

Fig. 3 Np65 expressed in the inner ear is not detectable in hair cells. A Mid-modiolar cochlear sections from $\mathrm{Nptn}^{+/+}$mice were labeled with DAPI and antibodies against PMCA2 and against neuroplastin 55 and 65 (Nptns, left) or specific for Np65 (Np65, right). Neuroplastin was detected in inner (IHCs) and outer hair cells (OHCs), but Np65 was not detected. Scale bar $=30 \mu \mathrm{m}$. B Cochlear whole mounts of $\mathrm{Nptn}^{+/+}$and $\mathrm{Nptn}^{-/-}$mice were labeled with DAPI, antibodies against PMCA2, and antibodies specific for Np65. Np65 could not be detected in inner (IHC) or outer hair cells (OHC). Scale bar $=20 \mu \mathrm{m}$. C Sections from the AC of $\mathrm{Nptn}^{+/+}, \mathrm{Nptn}^{-/-}, \mathrm{Nptn}^{\Delta l o x / l o x P r C r e E R T}$, and

was easily detected in the AC by immunohistochemistry (Fig. 3C). Western blot analysis of the inner ear of wild-type mice revealed Np65 (Fig. 3D). This indicates, that despite Np65 expression in the inner ear, adult inner and outer hair cells express only Np55. In inner hair cells, neuroplastin was restricted to the cell bodies, whereas it was localized specifically to the stereocilia of the outer hair cells (Fig. 2, Suppl. Fig. S3). Strikingly, this expression pattern matches the known restricted cell body expression of PMCA1 in
Nptn ${ }^{\text {lox/loxEmxlCre }}$ mice were labeled with antibodies specific for Np65 and antibodies detecting all PMCAs. Np65 was detected in the AC of $\mathrm{Nptn}^{+/+}$and in reduced quantity of $\mathrm{Nptn}^{\text {lox/loxEmxlCre }}$ mice, but not in $\mathrm{Nptn}^{-/-}$and $\mathrm{Nptn}^{\Delta l o x / l o x P r C r e E R T}$ mice. Notice that the expression of PMCAs depends on the expression of Np. Scale bar $=30 \mu \mathrm{m}$. D Western blot analysis of expression of neuroplastin and Np65 in the brain and the inner ear. Antibodies against neuroplastin 55 and 65 (Nptns) and specific for Np65 (Np65) detected the respective isoforms in the brain and the inner ear of $\mathrm{Nptn}^{+/+}$but not of $\mathrm{Nptn}^{-/-}$mice

inner hair cells (Fig. 2A, Suppl. Fig. S3 upper panel) and of PMCA2 in the stereocilia of outer hair cells (Fig. 2B, Suppl. Fig. S3 lower panel) as described by Fettiplace and Nam (2019). The different targeting of neuroplastin and PMCA1/PMCA2 complexes could be caused by differences in the structure of PMCA1 and PMCA2. A Leu-Ile motif in 'b'-tail splice variants promotes PMCA1b basolateral sorting in inner hair cells, whereas the targeting of PMCA2 depends on the size of the A-site-spliced insert (Grati et al. 
2006). Neuroplastin associates with PMCAs to functional complexes permitting $\mathrm{Ca}^{2+}$ extrusion (Herrera-Molina et al. 2017; Korthals et al. 2017; Schmidt et al. 2017; Gong et al. 2018), thus, it appears that either the PMCAs direct the differential subcellular localization of neuroplastin in inner and outer hair cells or that neuroplastin determines the localization of the PMCAs, possibly by interaction with further molecules. Indeed, neuroplastin is required for the delivery of PMCA to the cell surface membrane (Schmidt et al. 2017). Furthermore, the absence of neuroplastin resulted in less PMCA1 in inner hair cells and absence of PMCA2 in outer hair cell stereocilia of adult $\mathrm{Nptn}^{-/-}$mice (Fig. 2). The lack of PMCA2 in outer hair cell stereocilia was already obvious at an age of 18 days (Suppl. Fig. S3 lower panel) before a significant hair cell loss occurs (see below). This suggests that in the absence of neuroplastin, the $\mathrm{Ca}^{2+}$ homeostasis in hair cells is compromised leading to the observed hearing deficit. This mechanism is supported by the phenotype of PMCA2-deficient mice, which are completely deaf (Kozel et al. 1998).

At P18 in $\mathrm{Nptn}^{-/-}$, the morphology of the cochlea and in particular the hair cells appeared normal (Suppl. Fig. S3), whereas a considerable loss of hair cells was observed in adult mutants. Therefore, we quantified the hair cell degeneration in the organ of Corti in 4-5-month-old $\mathrm{Nptn}^{-/-}$mice using Myosin7a as a hair cell marker. The number of hair cells in the apical, middle, and basal areas of the cochlea was significantly reduced in $\mathrm{Nptn}^{-/-}(n=5)$ but not in Nptnlox/loxEmxlCre $(n=4)$ in comparison to $\mathrm{Nptn}^{+/+}$mice $(n=3)$ (Fig. 4). At this age, the number of spiral ganglion neurons (SGN) in the apical turn of the cochlea was slightly and in the middle and basal turns significantly reduced in $\mathrm{Nptn}^{-/-}(n=4)$ but not in Nptn lox/loxEmxICre $(n=3)$ in comparison to $\mathrm{Nptn}^{+/+}(n=3)$ mice (Fig. 5). Type I SGNs contact the inner hair cells via their peripheral dendrites and relay auditory information to the brainstem via their central axon fibers (for review, Reijntjes and Pyott 2016) whereas type II SGNs contact the outer hair cells (Spoendlin 1969). Both, type 1 and type 2 SGN are detected by the marker beta-III tubulin (TUJ) used by us. However, as type I SGN constitute about $95 \%$ and type II SGN constitute about $5 \%$ of the total SGN (Ryugo 1992), at least one-third of SGN type I must be lost to account for the observed reduction. Furthermore, the regular layered pattern of supporting cells was disturbed in $\mathrm{Nptn}^{-/-}$mice (Suppl. Fig. S4).

\section{Neuroplastin expression by glutamatergic neurons is not essential for hearing}

In $\mathrm{Nptn}^{\text {lox/loxEmxlCre }}$ mice, $\mathrm{Np}$ expression in glutamatergic central neurons is missing (Herrera-Molina et al. 2017), but neuroplastin expression by inner and outer hair cells (Figs. 2, 4) and SGN (Fig. 5) is indistinguishable from wild type.
Quantitative analysis of 4-5-month-old Nptn ${ }^{\text {lox/loxEmxlCre }}$ also did not reveal degeneration of hair cells or SGN (Figs. 4, 5). In agreement, the ABR of Nptn ${ }^{\text {lox/loxEmxlCre }}$ mice is normal (Fig. 1A). Basal resting brain activities detected by SPECT in Nptn ${ }^{\text {lox/loxEmxlCre }}$ were reported to differ from control mice in several areas (Herrera-Molina et al. 2017), yet auditory cortical activities were not significantly altered (Fig. 1B). Furthermore, the startle response and its PPI were normal in $\mathrm{Nptn}^{\text {lox/loxEmxlCre }}$ mice (Suppl. Fig. S1E) and Nptn ${ }^{\text {lox/loxEmxlCre }}$ mice did not show grossly altered cortical response patterns compared to wild-type mice (data not shown). These results show that the absence of neuroplastin from glutamatergic neurons in the brain does not interfere with perception, sensory motor gating, and processing of auditory stimuli. Whether neuroplastin in glutamatergic neurons may be required for more complex functions of the $\mathrm{AC}$ remains to be determined.

\section{Neuronal loss of neuroplastin increases hearing thresholds}

To examine, whether neuroplastin is also necessary for maintaining acoustic sensitivity in the auditory system of adult mice, we analyzed Nptn ${ }^{\Delta l o x / l o x P r C r e E R T}$ mice after inactivating Nptn in adult mice (age $\geq 3$ months) with the tamoxifen inducible cre-recombinase driven by the prion promoter. Two months after induction, Nptn ${ }^{\Delta l o x / l o x P r C r e E R T}$ mice respond similar to control mice to the tone presented during fear conditioning with enhanced freezing in a neutral environment (Fig. 6A), which is indicative of sufficient hearing capabilities to respond. Furthermore, when analyzed for memory of fear conditioning trained before induction at an age $\geq 3$ months, Nptn ${ }^{\Delta l o x / l o x P r C r e E R T}$ mice showed 10 weeks after induction $a$ reaction similar to control mice to the conditioned tone again indicating at least residual hearing (data not shown). In line with these observations, our previous data showed a normal startle response 6 weeks after induced loss of neuronal neuroplastin in adult mice (Nptn ${ }^{\Delta l o x / l o x P r C r e E R T}$, Bhattacharya et al. 2017, see ibid Fig. Suppl. 6D +E). However, the PPI of the startle response was reduced at lower prepulse intensities and significantly less at 85 and $88 \mathrm{~dB}$ prepulse intensities (Bhattacharya et al. 2017). To investigate, whether Nptn ablation in adulthood might lead to progressive hearing deficits we measured ABR and startle response and its PPI over time in Nptn ${ }^{\Delta l o x / l o x P r C r e E R T}$ and control Nptn ${ }^{l o x / l o x}$ mice before and at several time points after induction. In $N p t n^{\Delta l o x / l o x P r C r e E R T}$ mice that had developed normally and showed normal ABR, startle and PPI before induction at an age $\geq 3$ months, the threshold of the ABR increased (Fig. 6B) and the PPI of the startle response with lower prepulse intensities was reduced after neuroplastin ablation (Fig. 6D). However, the startle response itself (Fig. 6C) 


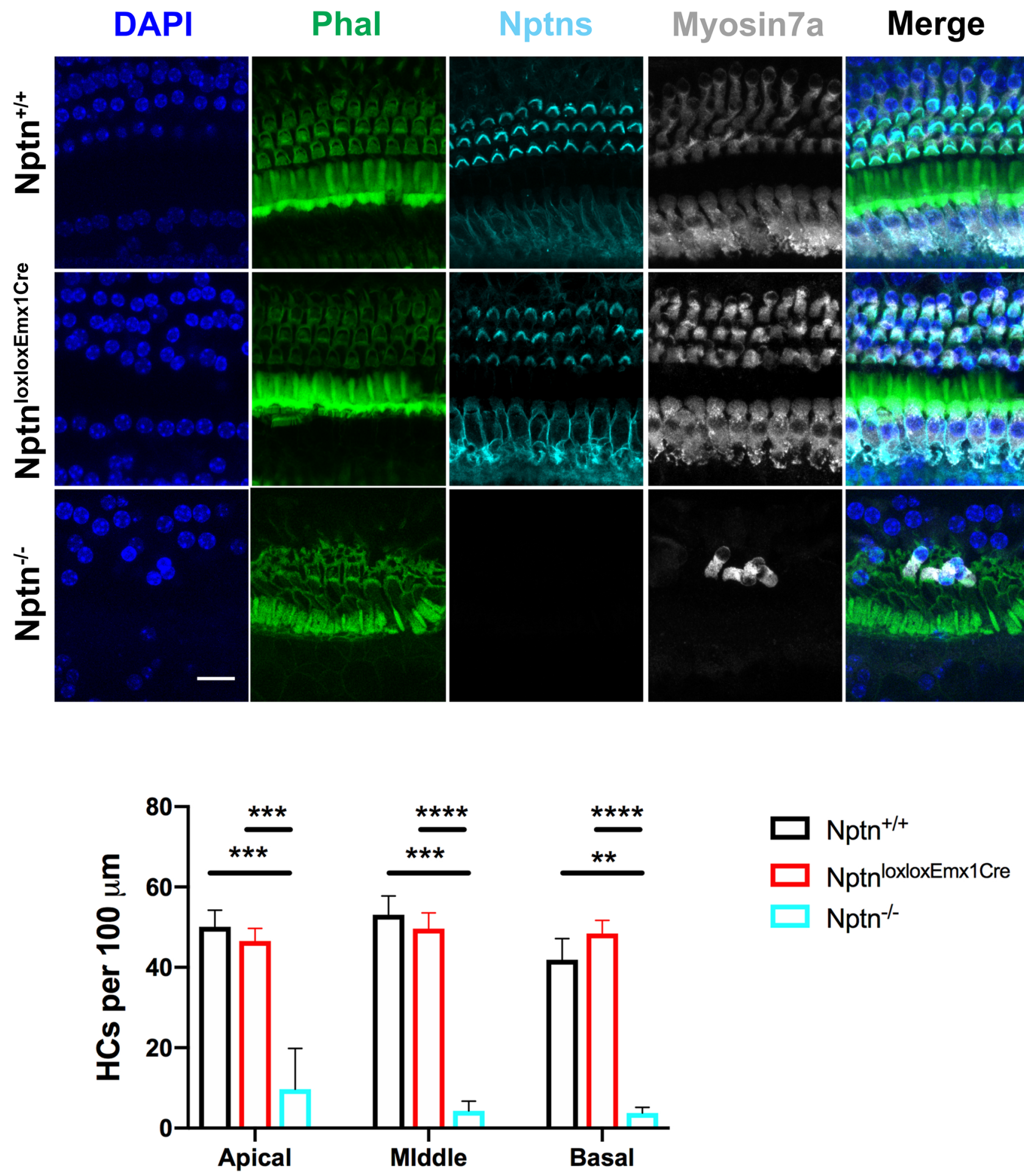

Fig. 4 Hair cell degeneration in $\mathrm{Nptn}^{-/-}$mice. Upper part: Representative images of the middle turn of cochlear whole mounts of 4-5-month-old $\mathrm{Nptn}^{+/+}, \mathrm{Nptn}^{-/-}$, and $\mathrm{Nptn}^{\text {lox/loxEmxlCre }}$ mice labeled with phalloidin-iFluor 488 green (Phal), DAPI, and antibodies against neuroplastin 55 and 65 (Nptns) and Myosin7a. Lower part: Quantification of hair cells identified by Myosin7a in 4-5-month-old $\mathrm{Nptn}^{+/+}$,
$\mathrm{Nptn}^{-/-}$, and Npth ${ }^{\text {lox/loxEmxlCre }}$ mice. The number of hair cells in the apical, middle, and basal areas of the cochlea is significantly reduced in $\mathrm{Nptn}^{-/-}(n=5)$ but not in Nptn ${ }^{\text {lox/loxEmxICre }}(n=4)$ in comparison to $\mathrm{Nptn}^{+/+}$mice $(n=3)$ (1-way ANOVA with Dunnett's multiple comparisons test, $* p \leq 0.05$; ** $p \leq 0.01$; *** $p \leq 0.001$; **** $p \leq 0.0001$ ). Scale bar $=15 \mu \mathrm{m}$ 
Fig. 5 Expression of neuroplastin in spiral ganglion neurons (SGN) of the cochlea. Upper part: Representative immunostaining of the middle part of the Rosenthal's canal of 4-5-month-old $\mathrm{Nptn}^{+/+}$, $\mathrm{Nptn}^{-/-}$, and Nptn lox/loxEmxiCre mice labeled with DAPI and antibodies against neuroplastin 55 and 65 (Nptns) and $\beta$-III Tubulin (TUJ). Lower part: Quantification of SGN identified by anti- $\beta$-III Tubulin staining in 4-5-month-old $\mathrm{Nptn}^{+/+}$, $\mathrm{Nptn}^{-/-}$, and Nptn lox/loxEmxICre mice. The number of SGN in the apical area of the cochlea is slightly and in the middle and basal areas significantly reduced in $\mathrm{Nptn}^{---}(n=4)$ but not in Nptn ${ }^{\text {lox/loxEmxICre }}(n=3)$ in comparison to $\mathrm{Nptn}^{+/+}(n=3)$ mice (1-way ANOVA with Dunnett's multiple comparisons test, $* p \leq 0.05 ; * * p \leq 0.01$; $* * * p \leq 0.001 ; * * * * p \leq 0.0001)$. Scale bar $=50 \mu \mathrm{m}$
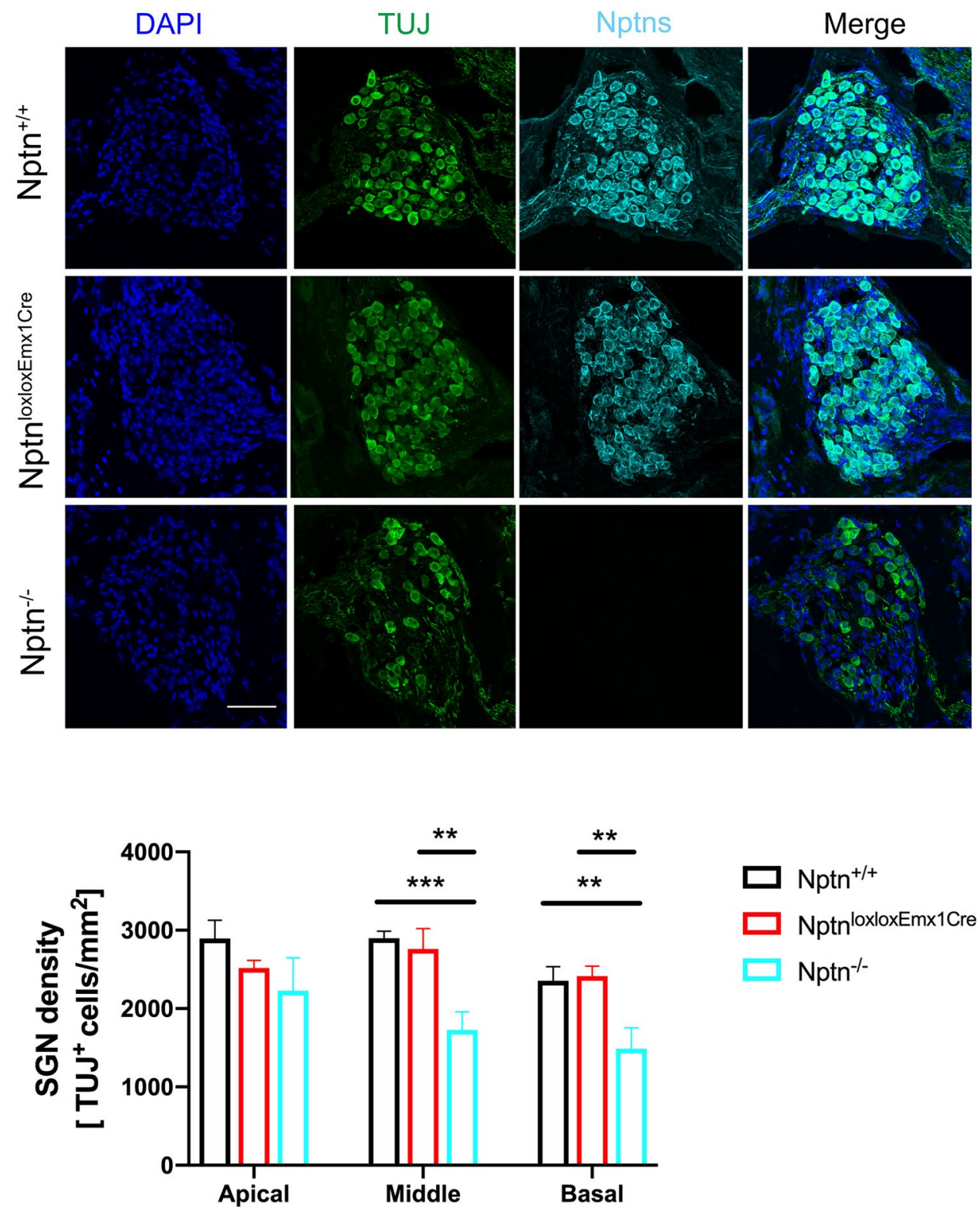

and PPI with high prepulse intensities remained and did not decline with time (Fig. 6D) in $\mathrm{Nptn}^{\Delta l o x / l o x P r C r e E R T}$ mice. These results suggest a partial hearing loss at lower sound intensities with residual perception of very high stimulus intensities as the consequence of neuroplastin loss in the adult. Indeed, residual neuroplastin expression by inner and outer hair cells after induction in Nptn ${ }^{\Delta l o x / l o x P r C r e E R T}$ mice correlated with the ABR threshold (Fig. 7). The number of outer and inner hair cells that express neuroplastin was significantly reduced after induction in $\mathrm{Nptn}^{\text {4lox/loxPrCreERT }}$ compared to control Nptn ${ }^{\text {lox/lox }}$ mice (Fig. 7B). Furthermore, the ABR threshold was correlated inversely $\left(R^{2}=0.9814\right)$ with the number of neuroplastin expressing outer hair cells (Fig. 7C).
Quantitative analysis revealed that the number of hair cells in the apical, middle, and basal turns of the cochlea was significantly reduced in $\operatorname{Nptn}^{\Delta l o x / l o x \operatorname{PrCreERT}}(n=3)$ in comparison to $\mathrm{Nptn}^{\text {lox/lox }}(n=4)$ mice 8 weeks after induced loss of neuroplastin in aged mice (Fig. 8A, C). In contrast, the expression of neuroplastin in SGN appeared not to be affected in $N p t n^{\Delta l o x / l o x P r C r e E R T}$ mice and the number of SGN was similar in $N p t n^{l o x / l o x}(n=4)$ and induced in $N_{p t n^{\Delta l o x / l o x P r C r e E R T}}(n=3)$ (Fig. 8B, D). Expression of neuroplastin in SGN of Nptn ${ }^{\Delta l o x / l o x P r C r e E R T}$ may be explained by either lack of prion promoter driven Cre expression or eventually by an extremely long half life time of neuroplastin in SGN. In any case, our data indicate that the hearing loss after induction is related to hair cell degeneration but not to $\mathrm{SGN}$ reduction. 

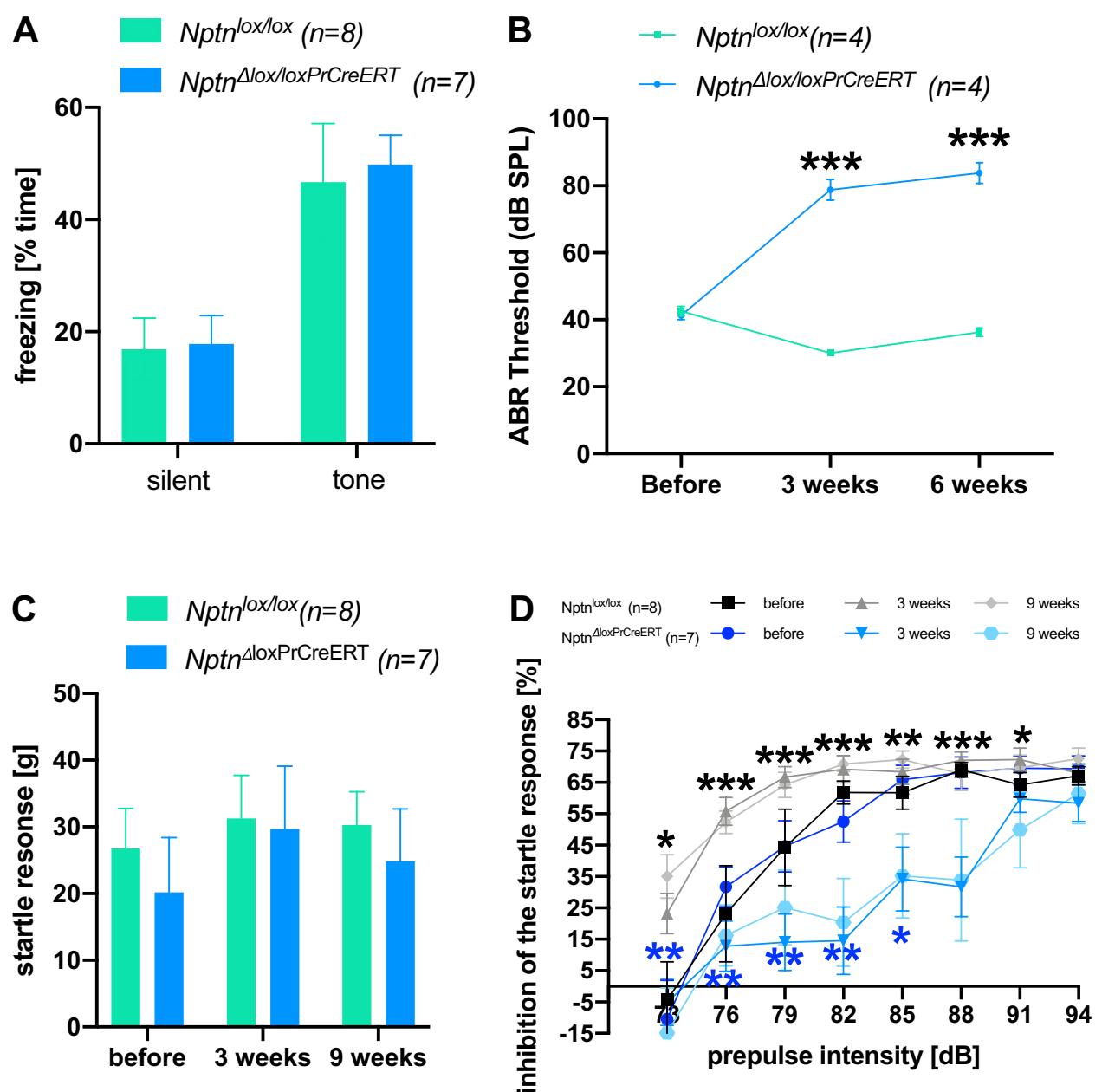

Fig. 6 Hearing after ablation of neuroplastin in the adult. A Freezing of induced $N p t n^{\Delta l o x / l o x P r C r e E R T}$ after fear conditioning in a neutral environment. 8 weeks after induction at an age $\geq 3$ months, $\mathrm{Nptn}^{\text {lox/lox }}$ controls ( $n=8$, green bars) and Nptn ${ }^{\text {Llox/loxPrCreERT }(~} n=7$, blue bars) mice were subjected to fear conditioning. One day later, the mice were exposed to a neutral environment with different shape, material, and color as the context during fear conditioning. Silent: freezing recorded in the neutral environment without tone; tone: freezing recorded in the neutral environment with the tone paired with foot shock during conditioning. All data are presented as means \pm SEM; differences were not significant (1-way ANOVA). B ABR of $N p t n^{\Delta l o x / l o x P r C r e E R T}\left(n=4\right.$, blue circles) and Nptn ${ }^{\text {lox/lox }}$ controls $(n=4$, green squares). Measurements were made at three time points: before induction with tamoxifen (before) at an age $\geq 3$ months, 3 weeks post-induction (3 weeks), and 6 weeks post-induction (6 weeks). All data are presented as means $\pm \mathrm{SEM}$; differences after induction were significant (1-way ANOVA, $* * * p \leq 0.001)$. C Startle response

In conclusion, our data show that in the complete absence of neuroplastin during development the peripheral hair cells fail resulting in deafness and prevention of auditory signal transmission to the AC. Neuroplastin expression by central glutamatergic neurons appears not to be required for auditory perception and processing of simple stimuli

of Nptn ${ }^{\Delta l o x / l o x P r C r e E R T}\left(n=7\right.$, blue bars) and Nptn ${ }^{\text {lox/lox }}$ controls $(n=8$, green bars). Measurements were made at three time points: before induction with tamoxifen (before) at an age $\geq 3$ months, 3 weeks post-induction ( 3 weeks), and 9 weeks post-induction ( 9 weeks). All data are presented as means $\pm \mathrm{SEM}$; differences were not significant (1-way ANOVA, $p>0.05)$. D PPI of the startle response of $N_{p t n}{ }^{\Delta l o x / l o x P r C r e E R T}\left(n=7\right.$, blue colors) and $\mathrm{Nptn}^{\text {lox/lox }}$ controls $(n=8$, grey colors). Inhibition in percent of the startle response without prepulse is presented as means \pm SEM. Measurements were made at three time points: before induction with tamoxifen (black squares, dark blue circles), 3 weeks post-induction (triangles, middle grey and middle blue), and 9 weeks post-induction (light grey diamonds, light blue hexagons). Significant differences after induction compared to the respective control are indicated (1-way ANOVA, ${ }^{*} p \leq 0.05$; ${ }^{* *} p \leq 0.01 ; * * * p \leq 0.001$, black stars: 3 weeks, blue stars: 9 weeks after induction)

(Emx1-promoterCre). When the development of the auditory system initially proceeded normally in the presence of neuroplastin, later loss of neuroplastin in adult hair cells resulted in significant increases in hearing thresholds but not in complete inability to respond to high intensity sounds. 


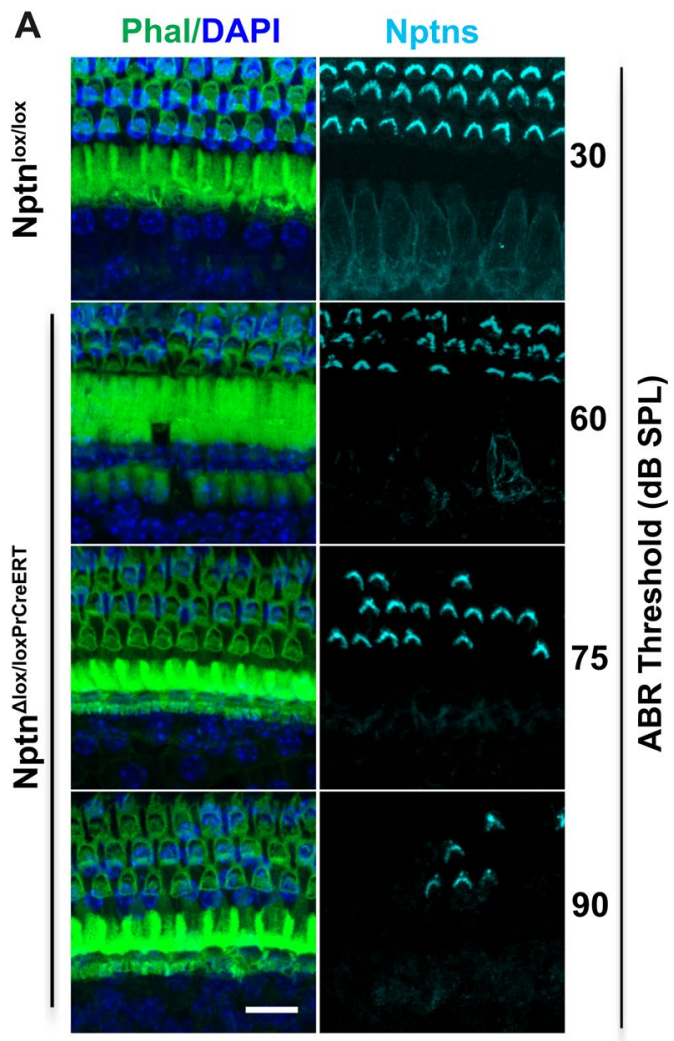

B

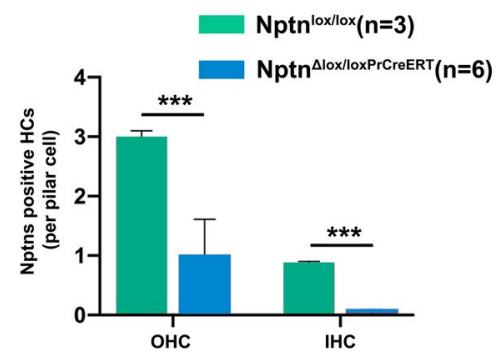

C

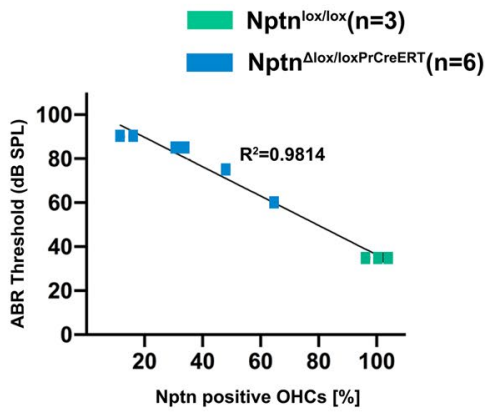

to $N p t n^{l o x / l o x}$ mice ( $n=3$, green). Normalized to pilar cells, the number of outer hair cells (OHC) expressing neuroplastin in stereocilia was strongly reduced (1-way ANOVA; $* * * p<0.001)$ and nearly all inner hair cells (IHC) lost expression of neuroplastin after induction in $N p t n^{\Delta l o x / l o x P r C r e E R T}$ mice (1-way ANOVA; $\left.* * * p<0.001\right)$. All data are presented as means \pm SEM. C ABR thresholds are inversely correlated with the percentage of $\mathrm{OHC}$ expressing neuroplastin analyzed in $\operatorname{Nptn}^{\Delta l o x / l o x P r C r e E R T}(n=6$, blue $)$ and Nptn ${ }^{\text {lox/lox }}$ mice $(n=3$, green $)$

When we determined the auditory thresholds at the auditory periphery/brainstem level, the ABR response in adult $\mathrm{Nptn}^{-/-}$mice showed very high thresholds above $90 \mathrm{~dB}$ revealing that these mice are deaf. In agreement, SPECT imaging of cerebral blood flow as a proxy for neural activity supported functional deficits in the auditory system of $\mathrm{Nptn}^{-/-}$mice with markedly reduced baseline activities in the AC compared to wild-type littermates. We further investigated whether lack of neuroplastin results in addition to the peripheral hearing deficit in altered signal processing in the auditory cortex. Although, basal synaptic transmission in the primary auditory cortex of $\mathrm{Nptn}^{-/-}$mice appeared normal with respect to input/output curves determined by field recordings in slices, subtle disturbances of synaptic plasticity in $\mathrm{Nptn}^{-/-}$mice are suggested by reduced prepulse facilitation at $40 \mathrm{~ms}$ intervals. Reduced prepulse facilitation was also described for the hippocampal Schaffer collaterals in $N p t n^{\Delta l o x / l o x P r C r e E R T}$ at short intervals, whereas $\mathrm{Nptn}^{-/-}$mice showed enhanced facilitation at larger intervals 
(Bhattacharya et al. 2017). Based on laminar CSD recordings during presentation of a salient click stimulus, we observed lack of tone-evoked synaptic input in the $\mathrm{AC}$ of adult $\mathrm{Nptn}^{-/-}$mice. Most likely, tone-evoked signals cannot be received and transmitted to the AC for processing. Unlike to muscimol-induced silencing of the AC (Happel et al. 2010; Deane et al. 2020), we did not detect robust and persisting thalamocortical inputs in the granular layers of 2-month-old $\mathrm{Nptn}^{-/-}$mice in response to pure tone stimulation. Moreover, we did not observe any type of acoustic evoked responses in 5-month-old $\mathrm{Nptn}^{-/-}$mice. The rudimentary cortical responses in the 2-month-old $\mathrm{Nptn}^{-/-}$mice (Fig. 3A) might hint at the progression of deafening and an early maladaptive overcompensation of thalamocortical inputs as a result of developmental deafening (Henschke et al. 2018).

We assume that the observed evoked responses in the 2-month-old mice might indicate an initial functional hearing, especially since the rudimentary evoked responses remained nearly consistent during the duration of the experiment. Eventually, the progression of hearing loss leads to the reduction of the thalamocortical inputs in the 5-month-old mice, resulting in a total loss of evoked responses (Chabot et al. 2015).

Our combined data show, that the complete loss of neuroplastin results in deafness already in the auditory periphery that explains the inability of adult $\mathrm{Nptn}^{-/-}$mice to behaviorally respond to auditory stimuli simply due to peripheral hearing loss. In agreement with the previous studies of other Nptn mouse mutants regarding neuroplastin as a deafness gene (Carrott et al. 2016; Zeng et al. 2016), our results underline that deafness can result from the absence of functional neuroplastin during development.

The residual cortical activities detectable in some young $\mathrm{Nptn}^{-/-}$mice might indicate initial development to a residual activity which is then lost with age leading to deafness in the absence of neuroplastin. This is in line with the suggested progressive hearing deterioration in very young pitch/pitch mutants (Carrott et al. 2016).

The conditional mutant inactivating the neuroplastin gene during development only in Emx1-expressing cells (central glutamatergic neurons) but not in hair cells or SGN of the cochlea shows functional hearing in adulthood. ABR thresholds of Nptn ${ }^{\text {lox/loxEmxlCre }}$ and wild-type mice do not differ and the behavioral responses to a fear associated tone are similar. Similarly, PPI of the startle response in these conditional mutants is not different from PPI of wild-type mice indicating normal processing and sensorimotor gating. These results indicate that neuroplastin expression by glutamatergic neurons in the brain is not required at any time for a functional auditory system. However, more subtle deficits of hearing or processing of auditory information in these mutants cannot be excluded and might be revealed by more complex hearing tasks. Similarly, neuroplastin expression by glutamatergic neurons is necessary for goal-directed behavior in the water maze (Herrera-Molina et al. 2017). Loss of neuroplastin from adult brain neurons and hair cells of the cochlea in $\mathrm{Nptn}^{\Delta l o x / l o x P r C r e E R T}$ mice led to increased hearing thresholds, but did not completely abolish responses to loud tones. It is well feasible that more complex and demanding auditory tasks may reveal the necessity for neuroplastin expression in the AC.

\section{Neuroplastin expression in the cochlear hair cells}

With our targeted $\mathrm{Nptn}^{-/-}$mice, that lack both isoforms $\mathrm{Np} 55$ and Np65, we cannot resolve, whether both or only one isoform is required for perception and processing of auditory information. Previous studies claimed that Np55 expressed by outer hair cells (Zeng et al. 2016) or Np65 expressed by inner hair cells (Carrott et al. 2016) in the cochlea is necessary for hearing. Our analysis clearly revealed that neuroplastin is expressed by both outer and inner hair cells in the cochlea. Furthermore, the subcellular distribution of $\mathrm{Np}$ differs between the hair cells with expression of $\mathrm{Np}$ only on the cell bodies of inner hair cells where it is colocalized with PMCA1 and expression of Np only in the stereocilia of the outer hair cells where it is colocalized with PMCA2. Interestingly, loss of $\mathrm{Np}$ is always accompanied with loss or reduction of the associated PMCA. By Western blot analysis, we could detect Np65 in the adult inner ear of wild-type mice (Fig. 3D). However, using immunohistochemistry, Np65 was easily detected in the AC but not in inner or outer hair cells (Fig. 3) or in spiral ganglia neurons or in supporting cells (data not shown) confirming that only Np55 is expressed by outer and inner hair cells of the adult cochlea. This is in line with the work of Zeng et al. (2016) but in contrast to the study of Carrott et al. (2016) showing expression of Np65 "localized to the cuticular plate of the IHCs and OHCs and the basolateral region of the IHCs" of the pitch heterozygous mutant. Eventually, the pitch missense mutation may cause this different expression pattern. It would be interesting to investigate the Np65-specific mutants generated by Amuti et al. (2016) for their hearing capacities. Amuti et al. (2016) reported reduced freezing of Np65-deficient mice to a conditioned cue of $87 \mathrm{~dB}$ which could indicate reduced hearing capacity and support a role of Np65 for hearing. However, our results indicate that Np65 is not expressed in cochlear hair cells but Np65 may play a role in auditory processing in the auditory pathway.

\section{Lack of neuroplastin reduces plasma membrane $\mathrm{Ca}^{2+}$ ATPases}

During development, neuroplastin serves functions as a cell recognition molecule and participates in synapse 


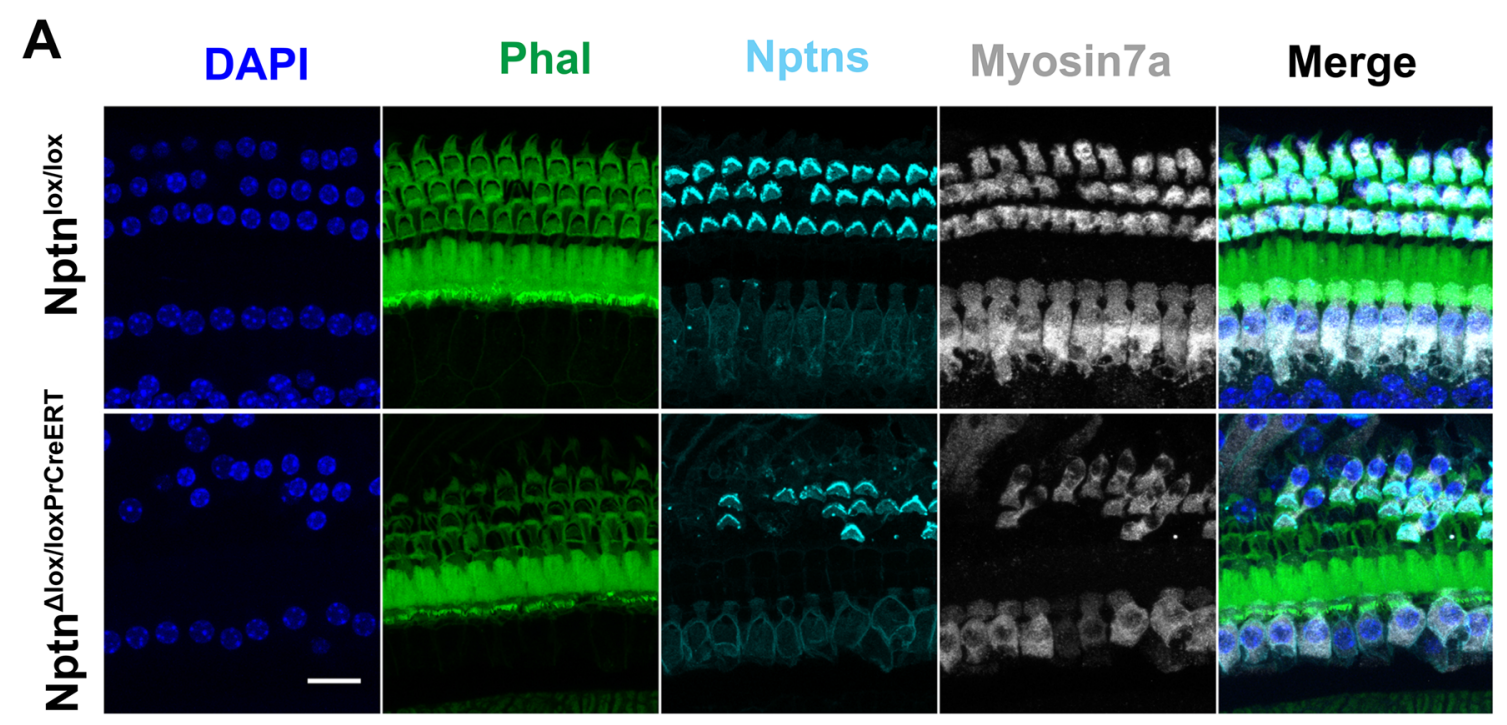

B

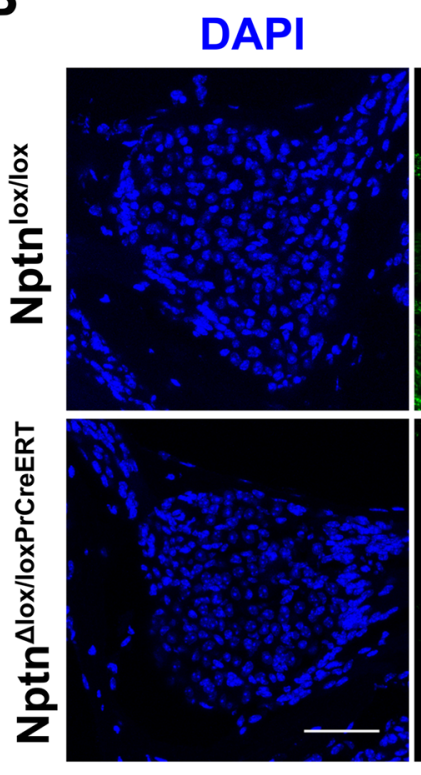

TUJ
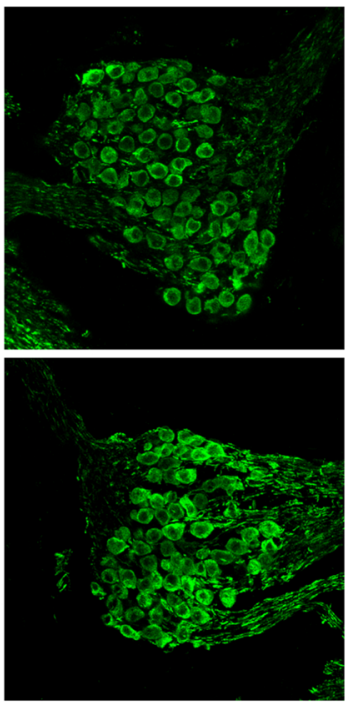

C

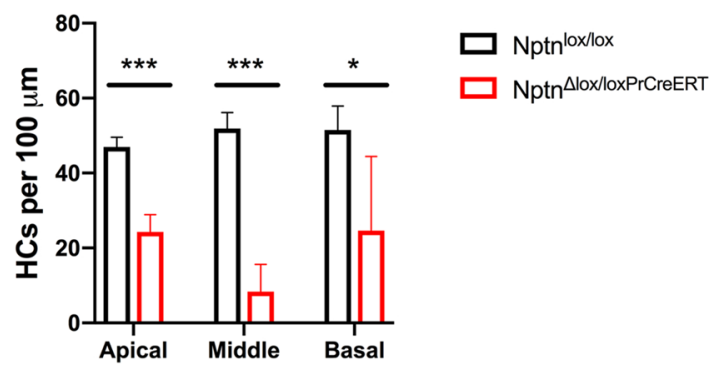

Nptins

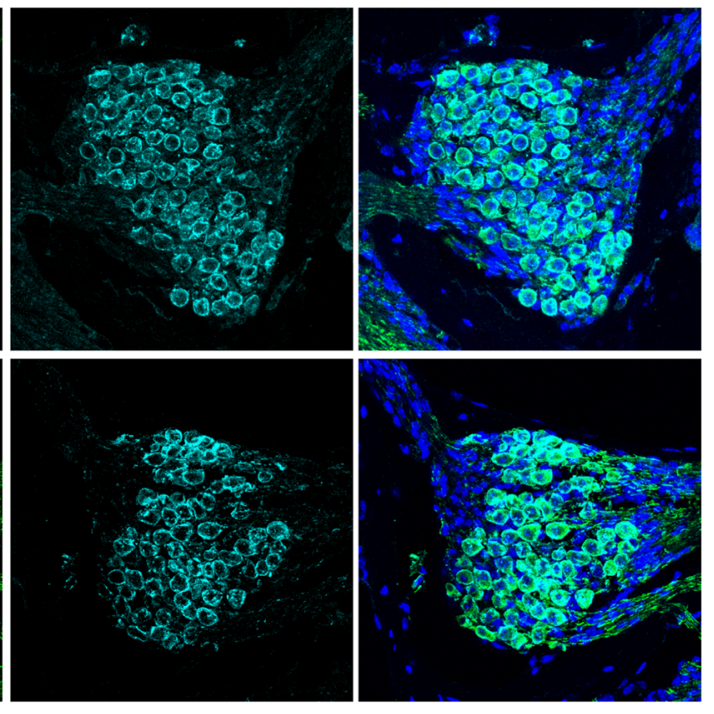

D

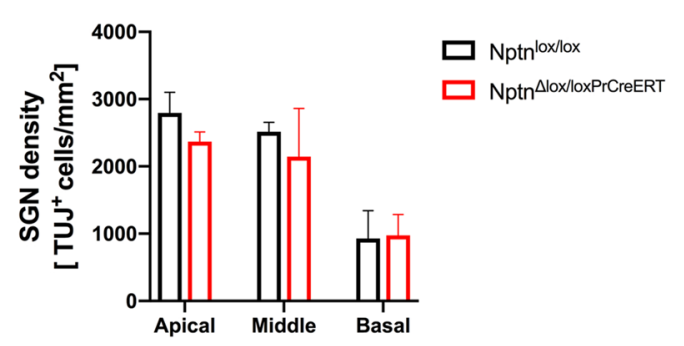

formation and plasticity (Herrera-Molina et al. 2014; Owczarek et al. 2011). Therefore, structural roles of neuroplastin during development of the ear as proposed by Zeng et al. (2016) and Carrott et al. (2016) are very well feasible. In addition, neuroplastin exerts further critical functions such as the stabilization of $\mathrm{Ca}^{2+}$ homeostasis in complexes with PMCA (Herrera-Molina et al. 2017; Korthals et al. 2017; Schmidt et al. 2017; Gong et al. 
4Fig. 8 Hair cell degeneration and maintenance of SGN in 9-10-month-old Nptn ${ }^{\text {Llox/loxPrCreERT }}$ mice 8 weeks after induced loss of neuroplastin. A Representative confocal images of the middle turn of the Organ of Corti of Nptn ${ }^{\text {lox/lox }}$ and Nptn ${ }^{\Delta l o x / l o x P r C r e E R T}$ mice labeled with phalloidin-iFluor 488 green (Phal), DAPI, and antibodies against neuroplastin 55 and 65 (Nptns) and Myosin7a revealing loss of hair cells in Nptn ${ }^{\Delta l o x / l o x P r C r e E R T}$ mice. Scale bar $=15 \mu \mathrm{m}$. B Representative immunostainings of the middle area of the Rosenthal's canal of $N p t n^{\text {lox/lox }}$ and $N p t n^{\Delta l o x / l o x P r C r e E R T}$ mice labeled with DAPI and antibodies against neuroplastin 55 and 65 (Nptns) and $\beta$-III Tubulin (TUJ). SGN still express neuroplastin. Scale bar $=50 \mu \mathrm{m}$. D Quantification of hair cells identified by Myosin7a in Nptn ${ }^{\text {lox/lox }}$ and Nptn ${ }^{\Delta l o x / l o x P r C r e E R T}$ mice. The number of hair cells in the apical, middle, and basal areas of the cochlea is significantly reduced in Nptn $n^{\Delta l o x / l o x P r C r e E R T}(n=3)$ in comparison to Nptn lox/lox $(n=4)$ mice (1-way ANOVA with Dunnett's multiple comparisons test, $* p \leq 0.05 ; * * p \leq 0.01 ; * * * p \leq 0.001)$. D Quantification of SGN identified by $\beta$-III Tubulin in Nptn lox/lox and $N p t n^{\Delta l o x / l o x P r C r e E R T}$ mice. In Nptn ${ }^{\Delta l o x / l o x P r C r e E R T}$, SGN still express neuroplastin after induction. The number of SGN in the apical, middle, and basal areas of the cochlea is not affected Nptn ${ }^{\Delta l o x / l o x P r C r e E R T}(n=4)$ in comparison to $N p t n^{l o x} / l o x$ mice $(n=3)$ (1-way ANOVA with Dunnett's multiple comparisons test)

2018). It has been shown that the hearing system is critically dependent on $\mathrm{Ca}^{2+}$ homeostasis and in particular cochlear inner and outer hair cells depend exclusively on PMCA1 and PMCA2 for $\mathrm{Ca}^{2+}$ extrusion, respectively (for review, see Fettiplace and Nam 2019). Thus, neuroplastin essentially ensures appropriate levels of PMCAs for optimal $\mathrm{Ca}^{2+}$ homeostasis. Our results support a mechanism that requires sufficient $\mathrm{Np}$-dependent expression of PMCA2 in hair cells during development for appropriate $\mathrm{Ca}^{2+}$ homeostasis.

When we permitted a normal development and then ablated neuroplastin expression in the neurons of adult animals, hearing thresholds increased with the loss of neuroplastin. Interestingly, we found a linear correlation between the number of outer hair cells expressing neuroplastin and the hearing threshold after ablation of the neuroplastin gene in adult mice. Noteworthy, outer hair cells serve to amplify the auditory signal. These data suggest, that reduced neuroplastin levels lead to a reduction in PMCAs resulting in altered $\mathrm{Ca}^{2+}$ homeostasis interfering with auditory reception and signal transduction but residual auditory sensitivity to perceive very loud stimuli remains.

In conclusion, our study shows that functional neuroplastin is essential for the normal development of the auditory system. The complete lack of neuroplastin during development leads to deafness. The processing of auditory click stimuli, pure tones, or white noise does not require expression of neuroplastin by central glutamatergic neurons. Once the auditory system has matured, neuronal neuroplastin is required for normal thresholds in response to acoustic stimulation and only very high-threshold hearing is maintained after the loss of neuroplastin.
Supplementary Information The online version contains supplementary material available at https://doi.org/10.1007/s00429-021-02269-w.

Acknowledgements We thank Karla Sowa for expert technical assistance with the behavioral experiments, Kathrin Ohl for expert technical assistance during animal surgery, and Juanjuan Chen for the help with the immunofluorescence. This work was supported by German Federal Ministry of Education and Research (BMBF grant CONICYT to EDG, DM, Karl-Heinz Smalla, and Constanze Seidenbecher) and by the China Scholarship Council (to XL and EZ). R.H-M. thanks the Center for Behavioral and Brain Sciences (LSA-fellowship) and the DAAD 57514679.

Funding Open Access funding enabled and organized by Projekt DEAL. This work was supported by German Federal Ministry of Education and Research (BMBF grant CONICYT to EDG, DM, KarlHeinz Smalla, and Constanze Seidenbecher) and by the China Scholarship Council (to XL). R.H-M. thanks the Center for Behavioral and Brain Sciences (LSA-fellowship) and the DAAD 57514679.

Availability of data and materials (data transparency) Available on request with specific Material Transfer Agreements.

Code availability (software application or custom code) Not applicable.

\section{Declarations}

Ethics approval All procedures were in accordance with institutional, state, and government regulations and approved by an ethics committee.

Consent to participate Not applicable.

Consent for publication Not applicable.

Conflicts of interest The authors declare that they have no conflict of interest.

Open Access This article is licensed under a Creative Commons Attribution 4.0 International License, which permits use, sharing, adaptation, distribution and reproduction in any medium or format, as long as you give appropriate credit to the original author(s) and the source, provide a link to the Creative Commons licence, and indicate if changes were made. The images or other third party material in this article are included in the article's Creative Commons licence, unless indicated otherwise in a credit line to the material. If material is not included in the article's Creative Commons licence and your intended use is not permitted by statutory regulation or exceeds the permitted use, you will need to obtain permission directly from the copyright holder. To view a copy of this licence, visit http://creativecommons.org/licenses/by/4.0/.

\section{References}

Amuti S, Tang Y, Wu S, Liu L, Huang L, Zhang H, Li H, Jiang F, Wang G, Liu X, Yuan Q (2016) Neuroplastin 65 mediates cognitive functions via excitatory/inhibitory synapse imbalance and ERK signal pathway. Neurobiol Learn Mem 127:72-83. https://doi.org/ 10.1016/j.nlm.2015.11.020 
Beesley P, Kraus M, Parolaro N (2014a) The neuroplastins: multifunctional neuronal adhesion molecules-involvement in behaviour and disease. Adv Neurobiol 8:61-89

Beesley PW, Herrera-Molina R, Smalla KH, Seidenbecher C (2014b) The neuroplastin adhesion molecules: key regulators of neuronal plasticity and synaptic function. J Neurochem 131(3):268-283. https://doi.org/10.1111/jnc. 12816

Bhattacharya S, Herrera-Molina R, Sabanov V, Ahmed T, Iscru E, Stöber F, Richter K, Fischer KD, Angenstein F, Goldschmidt J, Beesley PW, Balschun D, Smalla KH, Gundelfinger ED, Montag D (2017) Genetically-induced retrograde amnesia of associative memories after neuroplastin ablation. Biol Psychiatry 81(2):124135. https://doi.org/10.1016/j.biopsych.2016.03.2107

Brunk MGK, Deane KE, Kisse M, Deliano M, Vieweg S, Ohl FW, Lippert MT, Happel MFK (2019) Optogenetic stimulation of the VtA modulates a frequency-specific gain of thalamocortical inputs in infragranular layers of the auditory cortex. Sci Rep 9(1):20385. https://doi.org/10.1038/s41598-019-56926-6

Burkard R (2006) Calibration of acoustic transients. Brain Res 1091(1):27-31. https://doi.org/10.1016/j.brainres.2006.02.132

Carrott L, Bowl MR, Aguilar C, Johnson SL, Chessum L, West M, Morse S, Dorning J, Smart E, Hardisty-Hughes R, Ball G, Parker A, Barnard AR, MacLaren RE, Wells S, Marcotti W, Brown SDM (2016) Absence of neuroplastin-65 affects synaptogenesis in mouse inner hair cells and causes profound hearing loss. J Neurosci 36:222-234. https://doi.org/10.1523/JNEUROSCI.1808-15. 2016

Chabot N, Butler BE, Lomber SG (2015) Differential modification of cortical and thalamic projections to cat primary auditory cortex following early- and late-onset deafness. J Comp Neurol 523:2297-2320. https://doi.org/10.1002/cne.23790

Choy MK, Javierre BM, Williams SG, Baross SL, Liu Y, Wingett SW, Akbarov A, Wallace C, Freire-Pritchett P, Rugg-Gunn PJ, Spivakov M, Fraser P, Keavney BD (2018) Promoter interactome of human embryonic stem cell-derived cardiomyocytes connects GWAS regions to cardiac gene networks. Nat Commun 9(1):2526. https://doi.org/10.1038/s41467-018-04931-0. Erratum in: Nat Commun (2018) 9(1):4792.

Cruikshank SJ, Rose HJ, Metherate R (2002) Auditory thalamocortical synaptic transmission in vitro. J Neurophysiol 87:361-384

Deane KE, Brunk MGK, Curran AW, Zempeltzi MM, Ma J, Lin X, Abela F, Aksit S, Deliano M, Ohl FW, Happel MFK (2020) Ketamine anesthesia induces gain enhancement via recurrent excitation in granular input layers of the auditory cortex. J Physiol. https://doi.org/10.1113/JP279705

Deliano M, Brunk MGK, El-Tabbal M, Zempeltzi MM, Happel MFK, Ohl FW (2018) Dopaminergic neuromodulation of high gamma stimulus phase-locking in gerbil primary auditory cortex mediated by D1/D5-receptors. Eur J Neurosci 51(5):1315-1327. https://doi. org/10.1111/ejn.13898

Desrivières S, Lourdusamy A, Tao C, Toro R, Jia T, Loth E, Medina LM, Kepa A, Fernandes A, Ruggeri B, Carvalho FM, Cocks G, Banaschewski T, Barker GJ, Bokde AL, Büchel C, Conrod PJ, Flor H, Heinz A, Gallinat J, Garavan H, Gowland P, Brühl R, Lawrence C, Mann K, Martinot ML, Nees F, Lathrop M, Poline JB, Rietschel M, Thompson P, Fauth-Bühler M, Smolka MN, Pausova Z, Paus T, Feng J, Schumann G, IMAGEN Consortium (2014) Single nucleotide polymorphism in the neuroplastin locus associates with cortical thickness and intellectual ability in adolescents. Mol Psychiatry 20:263-274. https://doi.org/10.1038/mp.2013.197

Empson RM, Buckby LE, Kraus M, Bates KJ, Crompton MR, Gundelfinger ED, Beesley PW (2006) The cell adhesion molecule neuroplastin-65 inhibits hippocampal long-term potentiation via a mitogen-activated protein kinase p38-dependent reduction in surface expression of GluR1-containing glutamate receptors. J
Neurochem 99:850-860. https://doi.org/10.1111/j.1471-4159. 2006.04123.x

Endepols H, Sommer S, Backes H, Wiedermann D, Graf R, Hauber W (2010) Effort-based decision making in the rat: an [18F] fluorodeoxyglucose micro positron emission tomography study. J Neurosci 30:9708-9714. https://doi.org/10.1523/JNEUROSCI. 1202-10.2010

Fettiplace R, Nam JH (2019) Tonotopy in calcium homeostasis and vulnerability of cochlear hair cells. Hear Res 376:11-21. https:// doi.org/10.1016/j.heares.2018.11.002

Givre SJJ, Schroeder CEE, Arezzo JCC (1994) Contribution of extrastriate area V4 to the surface-recorded flash VEP in the awake macaque. Vis Res 34:415-428

Gong D, Chi X, Ren K, Huang G, Zhou G, Yan N, Lei J, Zhou Q (2018) Structure of the human plasma membrane Ca2+-ATPase 1 in complex with its obligatory subunit neuroplastin. Nat Commun 9:3623. https://doi.org/10.1038/s41467-018-06075-7

Grati M, Aggarwal N, Strehler EE, Wenthold RJ (2006) Molecular determinants for differential membrane trafficking of PMCA1 and PMCA2 in mammalian hair cells. J Cell Sci 119:2995-3007. https://doi.org/10.1242/jcs.03030

Happel MF, Jeschke M, Ohl FW (2010) Spectral integration in primary auditory cortex attributable to temporally precise convergence of thalamocortical and intracortical input. J Neurosci 30:1111411127. https://doi.org/10.1523/JNEUROSCI.0689-10.2010

Henschke JU, Oelschlegel AM, Angenstein F, Ohl FW, Goldschmidt J, Kanold PO, Budinger E (2018) Early sensory experience influences the development of multisensory thalamocortical and intracortical connections of primary sensory cortices. Brain Struct Funct 223:1165-1190. https://doi.org/10.1007/ s00429-017-1549-1

Herrera-Molina R, Sarto-Jackson I, Montenegro-Venegas C, Heine M, Smalla KH, Seidenbecher CI, Beesley PW, Gundelfinger ED, Montag D (2014) Structure of excitatory synapses and GABAA receptor localization at inhibitory synapses are regulated by neuroplastin-65. J Biol Chem 289:8973-8988. https://doi.org/10. 1074/jbc.M113.514992

Herrera-Molina R, Mlinac-Jerkovic K, Ilic K, Stöber F, Vemula SK, Sandoval M, Milosevic NJ, Simic G, Smalla KH, Goldschmidt J, Bognar SK, Montag D (2017) Neuroplastin deletion in glutamatergic neurons impairs brain functions and calcium regulation: implication for cognitive deterioration. Sci Rep 7:7273. https:// doi.org/10.1038/s41598-017-07839-9

Kolodziej A, Lippert M, Angenstein F, Neubert J, Pethe A, Grosser OS, Amthauer H, Schroeder UH, Reymann KG, Scheich H, Ohl FW, Goldschmidt J (2014) SPECT-imaging of activity-dependent changes in regional cerebral blood flow induced by electrical and optogenetic self-stimulation in mice. Neuroimage 103:171-180. https://doi.org/10.1016/j.neuroimage.2014.09.023

Korthals M, Langnaese K, Smalla KH, Kähne T, Herrera-Molina R, Handschuh J, Lehmann AC, Mamula D, Naumann M, Seidenbecher C, Zuschratter W, Tedford K, Gundelfinger ED, Montag D, Fischer KD, Thomas U (2017) A complex of neuroplastin and plasma membrane calcium ATPase controls T cell activation. Sci Rep 7:8358. https://doi.org/10.1038/s41598-017-08519-4

Kozel PJ, Friedman RA, Erway LC, Yamoah EN, Liu LH, Riddle T, Duffy JJ, Doetschman T, EL MillerML C, Shull GE (1998) Balance and hearing deficits in mice with a null mutation in the gene encoding plasma membrane Ca2+-ATPase isoform 2. J Biol Chem 273:18693-18696

Langnaese K, Beesley PW, Gundelfinger ED (1997) Synaptic membrane glycoproteins gp65 and gp55 are new members of the immunoglobulin superfamily. J Biol Chem 272:821-827

Li H, Liu Y, Gao X, Liu L, Amuti S, Wu D, Jiang F, Huang L, Wang G, Zeng J, Ma B, Yuan Q (2019) Neuroplastin 65 modulates anxietyand depression-like behavior likely through adult hippocampal 
neurogenesis and central 5-HT activity. FEBS J 286:3401-3415. https://doi.org/10.1111/febs.14865

Ma Y, Hof PR, Grant SC, Blackband SJ, Bennett R, Slatest L, McGuigan MD, Benveniste $\mathrm{H}$ (2005) A three-dimensional digital atlas database of the adult C57BL/ $6 \mathrm{~J}$ mouse brain by magnetic resonance microscopy. Neuroscience 135:1203-1215

Ma Y, Smith D, Hof PR, Foerster B, Hamilton S, Blackband SJ, Yu M (2008) Benveniste $\mathrm{H}$ (2008) In vivo 3D digital atlas database of the adult C57BL/6 J mouse brain by magnetic resonance microscopy. Front Neuroanat 2:1. https://doi.org/10.3389/neuro.05.001. 2008

Mitzdorf U (1985) Current source-density method and application in cat cerebral cortex: investigation of evoked potentials and EEG phenomena. Physiol Rev 65:37-100. https://doi.org/10.1152/physr ev.1985.65.1.37

Owczarek S, Kiryushko D, Larsen MH, Kastrup JS, Gajhede M, Sandi C, Berezin V, Bock E, Soroka V (2010) Neuroplastin-55 binds to and signals through the fibroblast growth factor receptor. FASEB J 24:1139-1150. https://doi.org/10.1096/fj.09-140509

Owczarek S, Soroka V, Kiryushko D, Larsen MH, Yuan Q, Sandi C, Berezin V, Bock E (2011) Neuroplastin-65 and a mimetic peptide derived from its homophilic binding site modulate neuritogenesis and neuronal plasticity. J Neurochem 117:984-994. https://doi. org/10.1111/j.1471-4159.2011.07269.x

Perny M, Roccio M, Grandgirard D, Solyga M, Senn P, Leib SL (2016) The severity of infection determines the localization of damage and extent of sensorineural hearing loss in experimental pneumococcal meningitis. J Neurosci 36:7740-7749. https://doi.org/10. 1523/JNEUROSCI.0554-16.2016

Reijntjes DOJ, Pyott SJ (2016) The afferent signaling complex: regulation of type I spiral ganglion neuron responses in the auditory periphery. Hear Res 336:1-16

Ryugo DK (1992) The auditory nerve: peripheral innervation, cell body morphology, and central projections. In: Popper AN, Fay RR (eds) The mammalian auditory pathway: neuroanatomy. Springer, New York, pp 34-93

Saito A, Fujikura-Ouchi Y, Kuramasu A, Shimoda K, Akiyama K, Matsuoka H, Ito C (2007) Association study of putative promoter polymorphisms in the neuroplastin gene and schizophrenia. Neurosci Lett 411:168-173

Sakaguchi M, Yamamoto M, Miyai M, Maeda T, Hiruma J, Murata H, Kinoshita R, Winarsa Ruma IM, Putranto EW, Inoue Y, Morizane S, Huh NH, Tsuboi R, Hibino T (2016) Identification of an S100A8 receptor neuroplastin- $\beta$ and its heterodimer formation with EMMPRIN. J Invest Dermatol 136:2240-2250. https://doi. org/10.1016/j.jid.2016.06.617

Saldeitis K, Happel MFK, Ohl FW, Scheich H, Budinger E (2014) Anatomy of the auditory thalamocortical system in the mongolian gerbil: nuclear origins and cortical field-, layer-, and frequencyspecificities. J Comp Neurol 522:2397-2430. https://doi.org/10. $1002 /$ cne. 23540

Sarto-Jackson I, Milenkovic I, Smalla KH, Gundelfinger ED, Kaehne T, Herrera-Molina R, Thomas S, Kiebler MA, Sieghart W (2012) The cell adhesion molecule neuroplastin-65 is a novel interaction partner of gamma- aminobutyric acid type A receptors. J Biol Chem 287:14201-14214. https://doi.org/10.1074/jbc.M111. 293175

Schilling S, Zeitschel U, Hoffmann T, Heiser U, Francke M, Kehlen A, Holzer M, Hutter-Paier B, Prokesch M, Windisch M, Jagla W, Schlenzig D, Lindner C, Rudolph T, Reuter G, Cynis H, Montag D, Demuth HU, Rossner S (2008) Glutaminyl cyclase inhibition attenuates pyroglutamate $\mathrm{A} \beta$ and Alzheimer's disease-like pathology in vivo. Nat Med 14:1106-1111. https://doi.org/10.1038/nm. 1872

Schmidt N, Kollewe A, Constantin CE, Henrich S, Ritzau-Jost A, Bildl W, Saalbach A, Hallermann S, Kulik A, Fakler B, Schulte
U (2017) Neuroplastin and basigin are essential auxiliary subunits of plasma membrane $\mathrm{Ca}^{2+}$-ATPases and key regulators of $\mathrm{Ca}^{2+}$ clearance. Neuron 96:827-838.e9. https://doi.org/10.1016/j.neuron.2017.09.038

Schroeder CE, Metha AD, Givre SJ (1998) A spatiotemporal profile of visual system activation revealed by current source density analysis in the awake macaque. Cereb Cortex 8:575-592

Smalla KH, Matthies H, Langnäse K, Shabir S, Böckers TM, Wyneken U, Staak S, Krug M, Beesley PW, Gundelfinger ED (2000) The synaptic glycoprotein neuroplastin is involved in long-term potentiation at hippocampal CA1 synapses. Proc Natl Acad Sci USA 97:4327-4332. https://doi.org/10.1073/pnas.080389297

Spoendlin H (1969) Innervation patterns in the organ of corti of the cat. Acta Otolaryngol 67:239-254

Sumardika IW, Chen Y, Tomonobu N, Kinoshita R, Ruma IMW, Sato H, Kondo E, Inoue Y, Yamauchi A, Murata H, Yamamoto KI, Tomida S, Shien K, Yamamoto H, Soh J, Futami J, Putranto EW, Hibino T, Nishibori M, Toyooka S, Sakaguchi M (2019) Neuroplastin- $\beta$ mediates S100A8/A9-induced lung cancer disseminative progression. Mol Carcinog 58:980-995. https://doi. org/10.1002/mc. 22987

Suzuki J, Imanishi E, Nagata S (2016) Xkr8 phospholipid scrambling complex in apoptotic phosphatidylserine exposure. Proc Natl Acad Sci USA 113:9509-9514. https://doi.org/10.1073/pnas. 1610403113

Thanos PK, Robison L, Nestler EJ, Kim R, Michaelides M, Lobo MK, Volkow ND (2013) Mapping brain metabolic connectivity in awake rats with $\mu$ PET and optogenetic stimulation. J Neurosci 33:6343-6349. https://doi.org/10.1523/JNEUROSCI.4997-12. 2013

Vemula SK, Malci A, Junge L, Lehmann AC, Rama R, Hradsky J, Matute RA, Weber A, Prigge M, Naumann M, Kreutz MR, Seidenbecher CI, Gundelfinger ED, Herrera-Molina R (2020) The interaction of TRAF6 with neuroplastin promotes spinogenesis during early neuronal development. Front Cell Dev Biol 8:579513. https://doi.org/10.3389/fcell.2020.579513

Vollmer M (2018) Neural processing of acoustic and electric interaural time differences in normal-hearing gerbils. J Neurosci 38:6949-6966

Wiegner A, Wright CG, Vollmer M (2016) Multichannel cochlear implant for selective neuronal activation and chronic use in the free-moving Mongolian gerbil. J Neurosci Methods 273:40-54

Wilson MC, Kraus M, Marzban H, Sarna JR, Wang Y, Hawkes R, Halestrap AP, Beesley PW (2013) The neuroplastin adhesion molecules are accessory proteins that chaperone the monocarboxylate transporter MCT2 to the neuronal cell surface. PLoS ONE 8:e78654. https://doi.org/10.1371/journal.pone.0078654

Wyckhuys T, Staelens S, Van Nieuwenhuyse B, Deleye S, Hallez H, Vonck K, Raedt R, Wadman W, Boon P (2010) Hippocampal deep brain stimulation induces decreased $\mathrm{rCBF}$ in the hippocampal formation of the rat. Neuroimage 52:55-61. https://doi.org/10.1016/j. neuroimage.2010.04.017

Yagi T, Asada R, Kanekura K, Eesmaa A, Lindahl M, Saarma M, Urano F (2020) Neuroplastin modulates anti-inflammatory effects of MANF. iScience 23:101810. https://doi.org/10.1016/j.isci. 2020.101810

Zeng WZ, Grillet N, Dewey JB, Trouillet A, Krey JF, Barr-Gillespie PG, Oghalai JS, Müller U (2016) Neuroplastin isoform Np55 is expressed in the stereocilia of outer hair cells and required for normal outer hair cell function. J Neurosci 36:9201-9216. https:// doi.org/10.1523/JNEUROSCI.0093-16.2016

Publisher's Note Springer Nature remains neutral with regard to jurisdictional claims in published maps and institutional affiliations. 